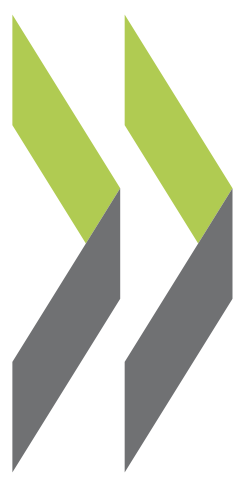

OECD Economics Department Working Papers No. 1296

\title{
Regulatory management practices in OECD countries
}

\section{Isabell Koske,}

Faisal Naru,

Philipp Beiter,

Isabelle Wanner 


\section{Unclassified}

ECO/WKP(2016)20

Organisation de Coopération et de Développement Économiques

Organisation for Economic Co-operation and Development

11-Apr-2016

ECONOMICS DEPARTMENT

English - Or. English

\section{REGULATORY MANAGEMENT PRACTICES IN OECD COUNTRIES}

\section{ECONOMICS DEPARTMENT WORKING PAPERS No. 1296}

By Isabell Koske, Faisal Naru, Philipp Beiter and Isabelle Wanner

OECD Working Papers should not be reported as representing the official views of the OECD or of its member countries. The opinions expressed and arguments employed are those of the author( $(s)$.

Authorised for publication by Jean-Luc Schneider, Deputy Director, Policy Studies Branch, Economics Department.

All Economics Department Working Papers are available at www.oecd.org/eco/workingpapers

JT03393791

Complete document available on OLIS in its original format

This document and any map included herein are without prejudice to the status of or sovereignty over any territory, to the delimitation of international frontiers and boundaries and to the name of any territory, city or area. 
OECD Working Papers should not be reported as representing the official views of the OECD or of its member countries. The opinions expressed and arguments employed are those of the author(s).

Working Papers describe preliminary results or research in progress by the author(s) and are published to stimulate discussion on a broad range of issues on which the OECD works.

Comments on Working Papers are welcomed, and may be sent to OECD Economics Department, 2 rue André-Pascal, 75775 Paris Cedex 16, France, or by e-mail to eco.contact@oecd.org.

All Economics Department Working Papers are available at www.oecd.org/eco/workingpapers.

This document and any map included herein are without prejudice to the status of or sovereignty over any territory, to the delimitation of international frontiers and boundaries and to the name of any territory, city or area.

The statistical data for Israel are supplied by and under the responsibility of the relevant Israeli authorities. The use of such data by the OECD is without prejudice to the status of the Golan Heights, East Jerusalem and Israeli settlements in the West Bank under the terms of international law.

\section{(C) OECD (2016)}

You can copy, download or print OECD content for your own use, and you can include excerpts from OECD publications, databases and multimedia products in your own documents, presentations, blogs, websites and teaching materials, provided that suitable acknowledgment of OECD as source and copyright owner is given. All requests for commercial use and translation rights should be submitted to rights@oecd.org 


\section{ABSTRACT/RESUMÉ}

\section{Regulatory management practices in OECD countries}

This paper provides analysis of the regulatory governance of network sector regulators in electricity, gas, telecommunications, rail, airport and ports within the OECD as it stood in 2013. The paper explores the governance arrangements of network sector regulators as described by law and analyses key institutional characteristics of network sector regulators such as appointments of board members, to whom regulators are formally accountable to, and what functions are most carried out by regulators. The paper also includes a new set of indicators on the regulatory management of the network sectors in terms of their independence, accountability and scope of action, reflecting the OECD Best Practice Principles on Regulatory Policy for the Governance of Regulators and as part of the updated 2013 Product Market Regulation (PMR) Indicators.

JEL classification codes : K2; L5

Keywords: regulator, network sector, governance, electricity, gas, telecommunications, rail transport, port, airport, independence, accountability, regulatory powers, economic regulator

$* * * * * * * * * * * * * * * * * * * * * * * *$

\section{Pratiques de gestion réglementaire dans les pays de l'OCDE}

Ce document fournit une analyse, au sein de l'OCDE, de la gouvernance des organismes de réglementation en vigueur en 2013 dans les secteurs de réseau, électricité, gaz, télécommunications, transport ferroviaire, aéroport et ports. Le document explore les modalités de gouvernance des organismes de réglementation des secteurs de réseau, comme décrit par la loi et analyse les caractéristiques institutionnelles fondamentales de ces organismes telles que les nominations des membres du conseil d'administration, auxquels les régulateurs doivent formellement rendre compte, et les fonctions le plus effectuées par les organismes de réglementation. Le document comprend également une nouvelle série d'indicateurs sur la gestion de la réglementation dans les industries de réseau en fonction de leur indépendance, leur responsabilité et la portée de leur action fondée sur le principe des meilleures pratiques de l'OCDE en terme de politique réglementaire pour la gouvernance des organismes de réglementation ; ces indicateurs s'inscrivent dans le cadre de la mise à jour 2013 des indicateurs de réglementation du marché des produits (RMP).

Codes JEL : K2; L5

Mots clé : organismes de réglementation, secteur de réseau, gouvernance, électricité, gaz, télécommunications, transport ferroviaire, ports, aéroports, indépendance, responsabilité, pouvoirs de réglementation, organismes de réglementation économique 


\section{TABLE OF CONTENTS}

\section{REGULATORY MANAGEMENT PRACTICES IN OECD COUNTRIES …........................................}

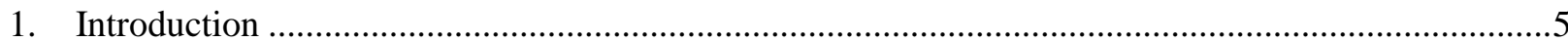

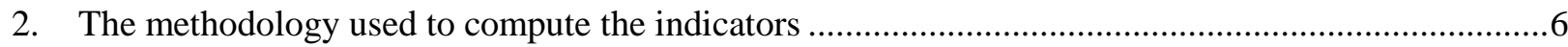

3. Regulatory management in network sectors - What do the indicators tell us? ................................10

4. Regulatory management in network sectors - What does the detailed data tell us? ...........................13

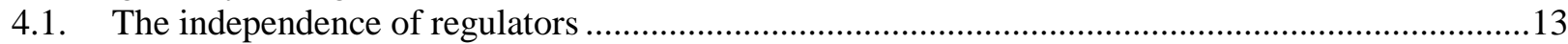

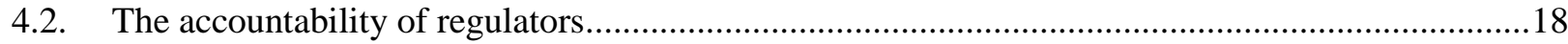

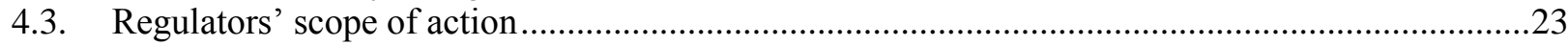

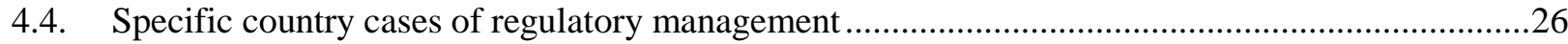

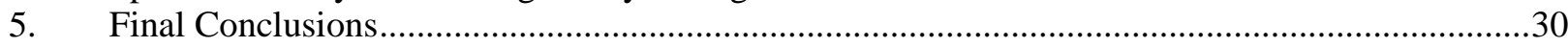

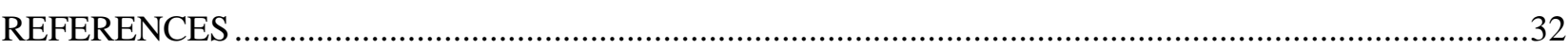

ANNEX: THE SCORING SYSTEM OF THEREGULATORY MANAGEMENT INDICATORS ............35

\section{Tables}

Table 1. Coverage rate of the regulatory management database .....................................................7

Table 2. The regulatory management indicators tend to be positively correlated across sectors .........12

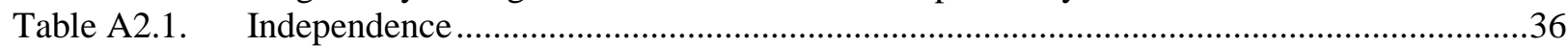

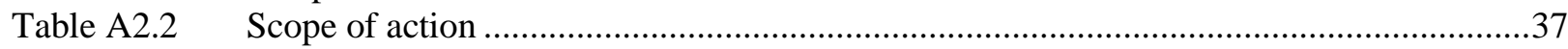

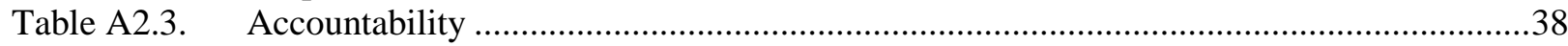

\section{Figures}

Figure 1. The governance of regulators in six network sectors …...................................................11

Figure 2. How is the status of the regulatory best described?.........................................................

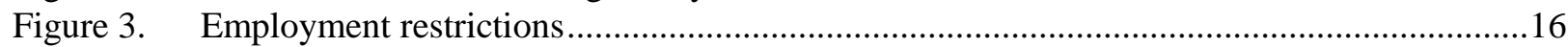

Figure 4. In which of the following cases can the regulator receive instructions or official guidance from the government or the parliament? .............................................................................18

Figure 5. To whom is the regulator directly accountable by law or statute? ...................................20

Figure 6. Does the regulator collect the following performance information? ..................................21

Figure 7. If such performance information is collected, is it available via the internet? ....................22

Figure 8. Activities of regulators (ministerial \& non-ministerial) .....................................................24

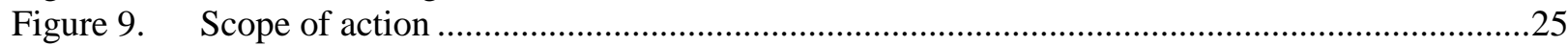

Figure 10. Balancing independence, accountability and scope of action .............................................31

\section{Boxes}

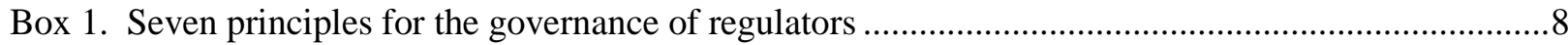

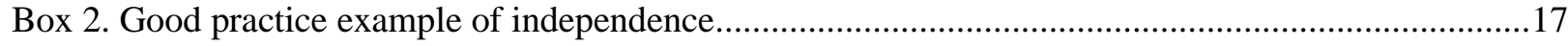

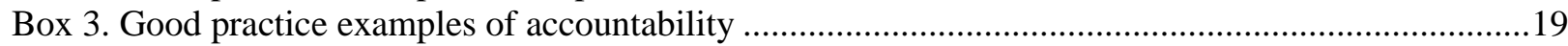

Box 4. Good practice examples of regulators' scope of action................................................................23 
ECO/WKP(2016)20

\title{
REGULATORY MANAGEMENT PRACTICES IN OECD COUNTRIES
}

\author{
Isabell Koske, Faisal Naru, Philipp Beiter, and Isabelle Wanner ${ }^{1}$
}

\section{Introduction}

1. A competition-friendly regulatory environment can help raise living standards by increasing investment, employment and productivity. A number of empirical studies have confirmed this link, including Bouis and Duval (2011), Bourlès et al. (2010), Conway et al. (2006) and Sutherland et al (2011). There are two important elements to a competition-friendly regulatory framework. First, regulations must be designed in a way that enhances competition and encourages firms to innovate and improve efficiency without being a too heavy burden on companies and, second, these regulations must be complied with or enforced in a transparent and cost-effective way. While in many areas of product markets, regulation is designed and implemented by the government, in network sectors, it is typically network regulators that take on this role.

2. Network sectors have historically been vertically integrated natural public monopolies before the introduction of competition in the market. ${ }^{2}$ In some instances the natural monopoly elements still exist such as in electricity distribution, which is why governance matters. The importance for effective regulatory institutions to facilitate the effective and fair operation of the market in network sectors is critical (Berg, 2000) in terms of investment (Jarvis and Sovacool, 2011), performance monitoring (Jenkins et al, 2007) and ultimately outcomes of the sector (Gutierrez, 2003; OECD 2015a).

3. This paper presents a new set of indicators that measure regulatory management practices in six network sectors: electricity, gas, telecom, railroad transport infrastructure, airports and ports. ${ }^{3}$ It is meant to complement the network components of the OECD's indicators of non-manufacturing regulation (NMR), which measure the regulations that are imposed on network sectors, by measures of the governance of the bodies that design, implement and enforce these regulations. The focus is on economic regulators, i.e. on institutions or bodies that are authorised by law to exercise regulatory powers over the sector for the purpose of setting prices and/or improving the operation of the market so that consumers have access to secure services and service providers receive a reasonable rate of return. Regulators that deal only with

1. The authors would like to thank Filippo Cavassini for his extensive comments, Dr. Sanford Berg, Nikolai Malyshev, Işık Özel and Alain de Serres for their useful comments and Santiago Gonzalez, Tobias Querbach and Vivial Leung for their work in supporting the analysis in this paper and Caroline Abettan for technical assistance and editing. In addition the comments and feedback from delegates of the OECD Regulatory Policy Committee and Network of Economic Regulators are very much appreciated who provided three rounds of fact-checking of the data-set. Special thanks go to the RPC delegates of Japan and Turkey and the NER delegates from Australia (Australian Consumer and Competition Commission), Mexico (Comisión Reguladora de Energía), United Kingdom (Office for Rail Regulation and Office for Gas and Electricity Markets). OECD Working Papers should not be reported as representing the official views of the OECD or of its member countries. The opinions expressed and arguments employed are those of the author(s).

2. See http://regulationbodyofknowledge.org/general-concepts/utility-market-reforms/

3. Specific analysis of the governance in the water sector has been conducted based on a survey of 34 regulators. See OECD (2015b). 
health, safety, or environmental issues are not considered. The indicators are computed for 33 OECD countries.

4. The remainder of this paper is organised as follows. It first briefly discusses the database that underlies the indicators and the methodology to compute them. It secondly presents the overarching indicators and presents general findings of regulatory management practices across OECD countries and sectors. It then examines the structure of regulators in greater detail in relation to their independence, accountability and scope of action. It also provides some specific country case examples. The paper is complemented by an Annex which gives further details on the methodology used to compute the indicators.

\section{The methodology used to compute the indicators}

5. The data on regulatory management practices in network sectors was gathered as part of the 2013 update of the OECD's product market regulation (PMR) database ${ }^{4}$. This database contains a large amount of information on regulatory structures and policies that is collected through a questionnaire sent to governments in OECD and non-OECD countries. The 2013 questionnaire contains around 1400 questions, of which a bit more than 300 deal with regulatory management practices in network sectors. ${ }^{5}$

6. The answers to the questionnaire went through a minimum of three rounds of official quality checking with the relevant government officials. In addition the regulatory management data was further checked through delegates of the OECD Regulatory Policy Committee and Network of Economic Regulators. The initial findings of the regulatory management data were presented and discussed at the meeting of the OECD Network of Economic Regulators in April 2014, and have been revised based on updated data and comments received.

7. The coverage rate of the regulatory management questions is generally very high (Table 1). Overall, the coverage rate of the dataset is $90 \%$ and for many countries the coverage rate is $100 \%$. Countries with a rather low coverage rate include Japan (35\%), Luxembourg (46\%) and Canada (58\%), typically because the questions were not answered for all of the seven sectors. For a given sector an indicator is computed whenever at least two-thirds of the data points are available.

4. The PMR Database and answers to the questionnaire can be found at: http://www.oecd.org/eco/growth/ indicatorsofproductmarketregulationhomepage.htm\#indicators

5. All OECD countries with the exception of the United States and the following non-OECD countries answered the questions on regulatory management practices and are thus covered by the analysis of this paper: Brazil, India, Russia and South Africa; Costa Rica, Dominican Republic, El Salvador, Jamaica and Nicaragua (in co-operation with the World Bank); Bulgaria, Croatia, Latvia, Lithuania, Malta and Romania (in co-operation with the European Commission). 
Table 1. Coverage rate of the regulatory management database

\begin{tabular}{|c|c|c|c|c|c|c|c|}
\hline & Electricity & Gas & $\begin{array}{l}\text { Telecommu- } \\
\text { nication }\end{array}$ & $\begin{array}{c}\text { Rail } \\
\text { transport }\end{array}$ & Airports & Ports & Total \\
\hline Australia & 100 & 100 & 100 & 100 & 100 & 100 & 100 \\
\hline Austria & 100 & 100 & 100 & 98 & 93 & 100 & 98 \\
\hline Belgium & 91 & 91 & 100 & 100 & 100 & 100 & 97 \\
\hline Canada & 0 & 0 & 100 & 85 & 81 & 93 & 58 \\
\hline Chile & 100 & 100 & 100 & 100 & 100 & 100 & 100 \\
\hline Czech Republic & 100 & 100 & 100 & 100 & 0 & 100 & 83 \\
\hline Denmark & 98 & 98 & 100 & 100 & 87 & 89 & 95 \\
\hline Estonia & 100 & 100 & 100 & 100 & 100 & 100 & 100 \\
\hline Finland & 100 & 100 & 100 & 100 & 98 & 100 & 100 \\
\hline France & 100 & 100 & 100 & 100 & 100 & 13 & 85 \\
\hline Germany & 100 & 100 & 100 & 98 & 100 & 100 & 100 \\
\hline Greece & 100 & 100 & 100 & 100 & 100 & 96 & 99 \\
\hline Hungary & 91 & 91 & 100 & 100 & 98 & 100 & 96 \\
\hline Iceland & 100 & 100 & 94 & 100 & 81 & 81 & 93 \\
\hline Ireland & 100 & 100 & 100 & 0 & 93 & 100 & 81 \\
\hline Israel & 100 & 100 & 100 & 98 & 98 & 98 & 99 \\
\hline Italy & 100 & 100 & 98 & 98 & 100 & 98 & 99 \\
\hline Japan & 87 & 87 & 2 & 46 & 0 & 0 & 35 \\
\hline Korea & 94 & 94 & 87 & 69 & 89 & 81 & 85 \\
\hline Luxembourg & 100 & 100 & 0 & 91 & 0 & 0 & 46 \\
\hline Mexico & 100 & 100 & 100 & 100 & 98 & 100 & 100 \\
\hline Netherlands & 98 & 98 & 100 & 100 & 98 & 100 & 99 \\
\hline New Zealand & 98 & 98 & 100 & 100 & 100 & 100 & 99 \\
\hline Norway & 100 & 100 & 98 & 98 & 100 & 100 & 99 \\
\hline Poland & 96 & 96 & 93 & 96 & 93 & 100 & 96 \\
\hline Portugal & 100 & 100 & 100 & 100 & 100 & 89 & 98 \\
\hline Slovak Republic & 100 & 100 & 100 & 100 & 0 & 100 & 83 \\
\hline Slovenia & 100 & 100 & 100 & 94 & 37 & 78 & 84 \\
\hline Spain & 100 & 100 & 100 & 94 & 98 & 100 & 99 \\
\hline Sweden & 98 & 98 & 100 & 100 & 100 & 100 & 99 \\
\hline Switzerland & 100 & 100 & 100 & 98 & 98 & 96 & 99 \\
\hline Turkey & 98 & 98 & 93 & 57 & 0 & 80 & 70 \\
\hline United Kingdom & 100 & 100 & 100 & 100 & 100 & 100 & 100 \\
\hline
\end{tabular}

Note: The coverage rate is defined as the number of non-missing values as a proportion of the total number of questions.

8. How a regulator is funded, staffed and held to account coupled with its responsibilities and duties, is crucial to the overall quality and effectiveness of regulation. The design of the indicators is motivated by the 2012 recommendations of the council on regulatory policy and governance (OECD, 2012a) which were translated in the OECD Best Practice Principles for the Governance of Regulators (2014) into seven principles for the governance of regulators (Box 1). 


\section{Box 1. Seven principles for the governance of regulators}

1. Role clarity: For a regulator to understand and fulfil its role effectively it is essential that its objectives and functions are clearly specified in the establishing legislation. The regulator should not be assigned objectives that are conflicting or should be provided with management and resolution mechanisms in case of conflicts. The legislation should also provide for clear and appropriate regulatory powers in order to achieve the objectives and regulators should be explicitly empowered to cooperate and coordinate with other relevant bodies in a transparent manner.

2. Preventing undue influence and maintaining trust: Independence from the government and from the industry that is regulated can improve the regulatory outcomes by allowing the regulator to make decisions that are fair and impartial. It is important that regulatory decisions and functions are conducted with upmost integrity to ensure that there is confidence in the regulatory regime. This is even more important for ensuring rule of law, encouraging investment and having an enabling environment for inclusive growth built on trust. Independence from the government and from the industry that is regulated can improve the regulatory outcomes by allowing the regulator to make decisions that are fair and impartial. This requires a proactive approach to regulating that is accessible by regulated entities and yet within the national strategic priorities. To maintain trust in the regulator, directions and communication with the political process should be clear and transparent. In addition there should be criteria for the employment of the governing body and staff of the regulator that protects from any conflicts of current or future interest. Formally protecting the independence of a regulator is an important element of achieving independence, even though it is not sufficient since a strong culture of independence and appropriate working relationships with the government and other stakeholders must also be in place (Thatcher, 2005; Gilardi and Maggetti, 2010).

3. Decision-making and governing body structure for independent regulators: Regulators require governance arrangements that ensure their effective functioning preserve its regulatory integrity and deliver the regulatory objectives of its mandate. The governing body structure of the regulator (e.g. a single head or a board of directors) should be determined by the nature of the regulated activities and their motivation. The membership of the governing body should also protect from potential conflicts of interest or influence from the political process and should be ultimately for the public interest.

4. Accountability and transparency: Businesses and citizens expect $(I)$ the delivery of regulatory outcomes from government and regulatory agencies; (ii) the proper use of public authority and the resources to achieve them. Regulators are generally accountable to three groups of stakeholders: (i) ministers and the legislature; (ii) regulated entities; (iii) the public. A regulator operates in accordance with the powers conferred to it by the legislature. Accountability and transparency can therefore be considered as the other side of the coin of independence. The expectations for the regulator should be published and Regulators should regularly report on the fulfilment of their objectives, including through meaningful performance indicators (see OECD 2015a). Key operational policies and other guidance material, covering matters such as compliance, enforcement and decision review should be publicly available. Regulated entities and the public should have the right of appeal preferably through a judicial process and the opportunity for independent review of significant regulatory decisions should be available.

5. Engagement: Good regulators have established mechanisms for engagement with stakeholders as part of achieving their objectives. The knowledge of regulated sectors, businesses and citizens affected by regulatory schemes assists to regulate effectively. Regulators should also regularly and purposefully engage with regulated entities and other stakeholders to enhance public and stakeholder confidence in the regulator and to improve regulatory outcomes.

6. Funding: The amount and source of funding for a regulator will determine its organisation and operations. It should not influence the regulatory decisions and the regulator should be enabled to be impartial and efficient to achieve its objectives. Funding levels should be adequate and funding processes should be transparent, efficient and simple.

7. Performance evaluation: It is important that regulators are aware of the impacts of their regulatory actions and decisions. This helps drive improvements and enhance systems and processes internally. It also demonstrates the effectiveness of the regulator to those it is accountable toward and helps to build confidence in the regulatory system. The regulatory decisions, actions and interventions of the regulator should be evaluated through performance indicators. This creates awareness and understanding of the impact of the regulator's own actions and helps to communicate and demonstrate to stakeholders the added value of the regulator.

Source: OECD Best Practice Principles for Regulatory Policy: The Governance of Regulators (2014). 
9. The independence of regulators is not simple to define and is discussed in detail in the Governance of Regulators Principles. A regulator can be part of a ministry and yet be more "independent" than a regulator that is a separate body. In other words having a "culture of independence" is critical ${ }^{6}$. Independence is a complex and multifaceted issue especially because regulators are inevitably part of the policy-making process which requires almost daily interactions between public and private institutions and stakeholders. Independence cannot be therefore taken as the complete insulation of the regulator. ${ }^{7}$ The indicators start to identify the specific procedures that could enhance the regulator's ability to make decisions and take actions on economic regulation without political interference or undue influence from the regulated sector on, for example, agency head/board appointments and dismissals, regulatory decisions and the daily management of human and financial resources.

10. The objective of independence is not to disconnect the regulator from policy making. It is rather to ensure that the regulator is sufficiently shielded from short-term political considerations - or undue influence - in order to promote a stable and credible regulatory environment that facilitates a long-term view on the provision and functioning of the network market such as in relation to investment. At the same time it is key to guarantee the integrity of the regulator vis-à-vis industry to address the shortcomings that usually characterise the markets for which network sector regulators are responsible for, including monopolistic behaviour and asymmetric information. Avoiding "undue" influence from the regulated industry and sector can ensure trust of citizens (i.e. the end users of network industries) in an unbiased regulatory environment: users can thus make decisions that fit their preferences and provide the "right" signals to markets.

11. Independence cannot mean that regulators operate without appropriate checks on their work. Accountability requires open and transparent processes on the decisions taken by the regulator and the performance of the regulator in terms of achieving its objectives and facilitating positive outcomes for the regulated market and sector. Accountability is hard to realise if the roles and respective responsibilities and scope of action of the executive government and regulators are unclear and ill-defined. Little clarity on the respective roles creates "grey areas" where the decisions on policy priorities and objectives (the responsibility of elected governments) are mixed with regulatory decisions that should contribute to achieving these objectives (the responsibility of independent regulators). Setting clear and transparent boundaries on who does what and on what each institution can be held accountable for is essential to guarantee the effectiveness of the work of the regulator (and the government).

12. Having in mind these considerations and drawing on the seven principles, the indicator for each sector is constructed as the simple average over three components.

- Independence: This component is meant to capture the insulation of the regulator from undue influence by the government and representatives of the regulated sectors. It draws mostly on the second and third principle above, asking whether the regulator can receive instructions from the executive, whether its independence is explicitly stated in the law, which bodies can overturn the regulator's decisions and how staff is recruited and dismissed. While the component also deals with funding (the sixth principle) the focus of the indicator is not on the level of funding but on whether the sourcing is balanced in the funds come equally from the regulated industry and the government.

6. See "Being an Independent Regulator: the what and the how", GOV/RPC/NER(2015)4, OECD Publishing (forthcoming).

7. See, for example, the interesting considerations in this sense concerning competition authorities presented in Kovacic (2011). 
- Accountability: This component captures the accountability of the regulator vis-à-vis various stakeholders, including the government, the regulated industry and the general public. It directly draws on the first, fourth, fifth and seventh governance principle, asking, for instance, to whom the regulator is accountable by statute, whether it collects and publishes various types of performance information, whether it publishes a report on its activities and whether it engages in public consultations and hearings.

- Scope of action: This component captures in part the first principle and also sheds light on the range of activities that the regulator performs. It captures matters such as whether the regulator has a purely advisory role or decision making and enforcement powers, whether it can collect information from regulated entities by compulsory process, and whether it can issue sanctions and penalties in the case of non-compliance with regulatory standards.

\section{Regulatory management in network sectors - What do the indicators tell us?}

13. Figure 1 shows countries' scores on the indicators for the six network sectors. Scores vary from 0 (the most effective governance structure) to 6 (the least effective governance structure). The following findings are worth mentioning:

- Governance structures are found to vary across sectors, being weakest for ports (the average score across countries is equal to 2.96) and strongest for telecommunications (1.91). With average indicator values of respectively 2.13 and 2.19 , governance also tends to be strong in gas and electricity, though slightly less so than in telecommunications.

- The governance of sector regulators - their independence, scope of action and accountability varies considerably across countries. Overall, the United Kingdom, Italy and Germany appear to have the strongest governance structures for sector regulators among OECD countries. Countries that have a comparatively strong governance structure in one sector also tend to be among the better performing countries in the other sectors, as suggested by the mostly positive correlations in Table $1 .^{8}$

- While most regulators are formally "independent bodies with adjudicatory, rule-making or enforcement powers", there is a fair degree of variety with respect to their institutional set-up and context. Despite the formal independence it is common that the government performs a "corrective or checking function" and provides guidance and instructions to the regulator. This indicates that independence is a much more complex concept than the legal status alone may suggest. A considerable number of countries have regulators that are part of ministries. Regulators integrated within a ministry and financed from the state budget are much more predominant in the transport sectors (rail, airports and ports) than in the other sectors. Overall there are very few independent regulators with a purely advisory role.

- There is a great variety in terms of the activities that regulators perform (both across countries and sectors). The scope of action indicator is the lowest for telecom regulators and generally quite high for regulators in transport sectors. It is quite common that at least some of the activities performed by a regulator are done together with another agency or body such as courts, a ministry or the competition agency. This suggests that designing effective structures for coordination and co-operation at all levels of government is important for effective regulatory management.

8. The high correlation between electricity and gas is driven by the fact that in many countries the two sectors are regulated by the same agency. 
- Most regulators are accountable to the government or the parliament. At the same time most regulators have to implement various measures of transparency vis-à-vis the wider public, including in particular the publication of reports on their activities, the publication of their decisions, resolutions and agreements, and the conduct of public consultations. Also the compilation and publication of performance information is very common, with the notable exception of information on organisational performance (e.g. number of staff trainings). On average across countries, regulators in the telecom sector and the two energy sectors display a higher degree of accountability than regulators in the three transport sectors.

14. The indicators only reflect the de jure situation, as such they do not capture cases were regulators conform to established practices but are not legally bound to do so through a formal or codified requirement. For instance, in several cases the publication of a forward-looking action plan is not imposed by law but is normally part of the authority's annual report (e.g. gas and electricity regulator in Australia and Italy, rail transport regulator in the Slovak Republic and the United Kingdom, and air transport regulator in Ireland). Also various other measures of transparency might be implemented by regulators without a legal obligation to do so (this is for instance the case in South Africa where the ports regulator holds public consultations and publishes its decisions, resolutions and agreements as well as the instructions and official guidance received from the government ${ }^{9}$ ).

Figure 1. The governance of regulators in six network sectors

Panel A: Independence

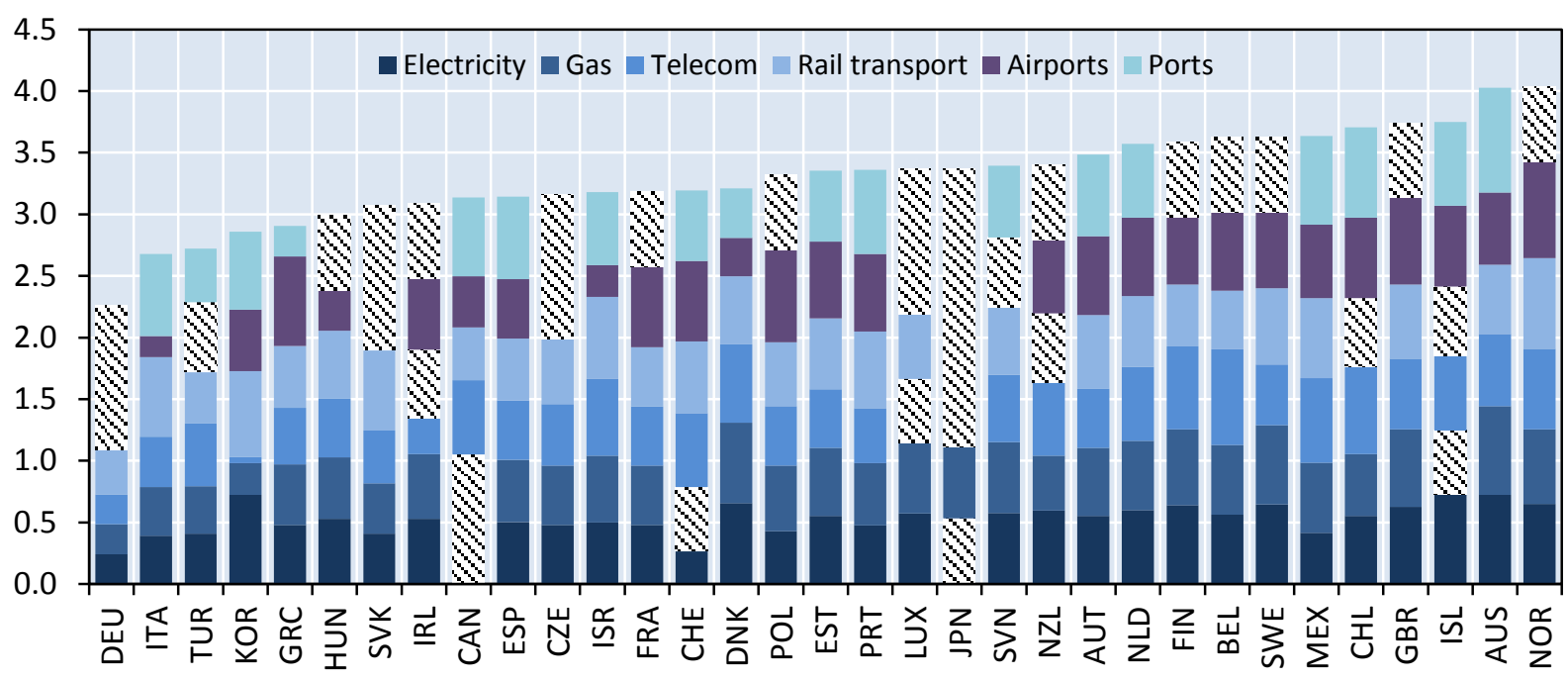

9. The indicators in this paper do not include the 18 non-OECD countries, while information on the network sectors was collected as part of the 2013 update of the OECD PMR indicators. 
Panel B: Accountability

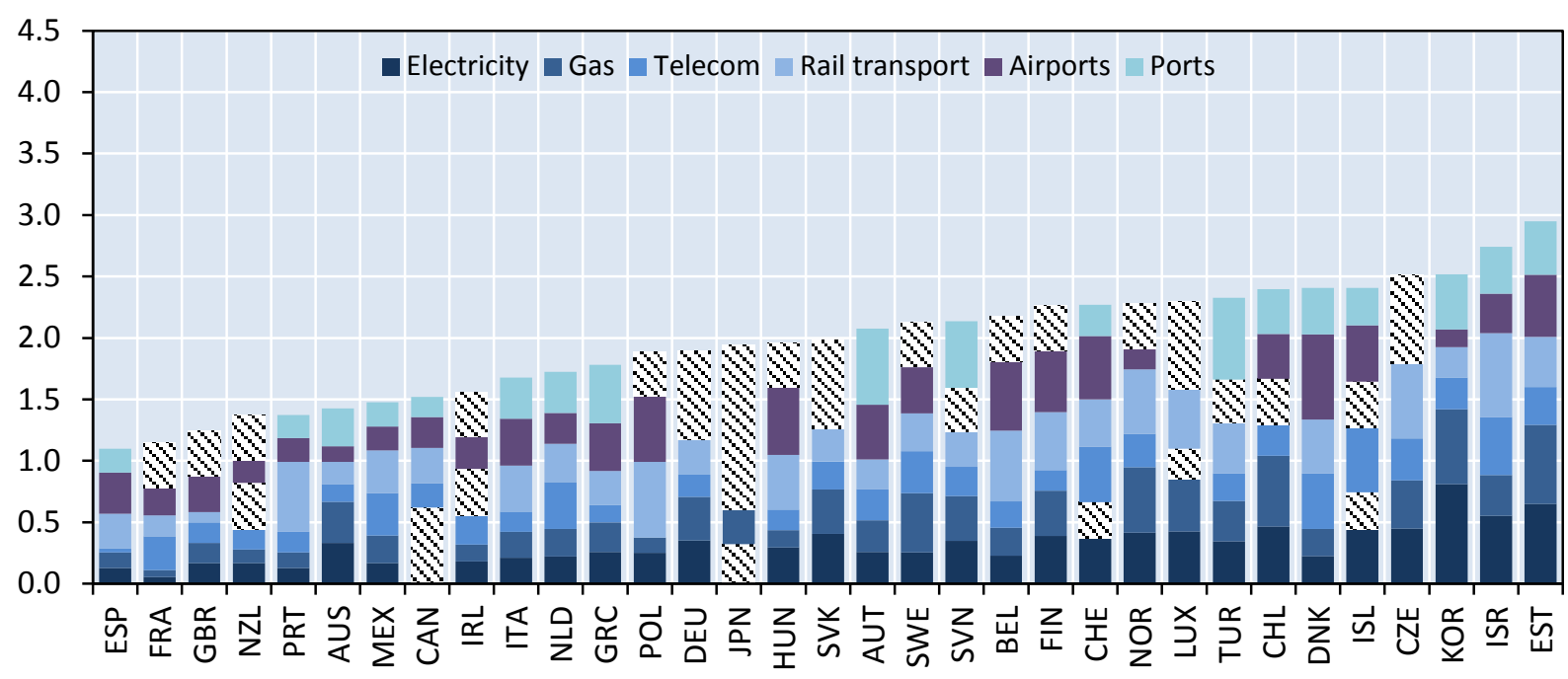

Panel C: Scope of Action

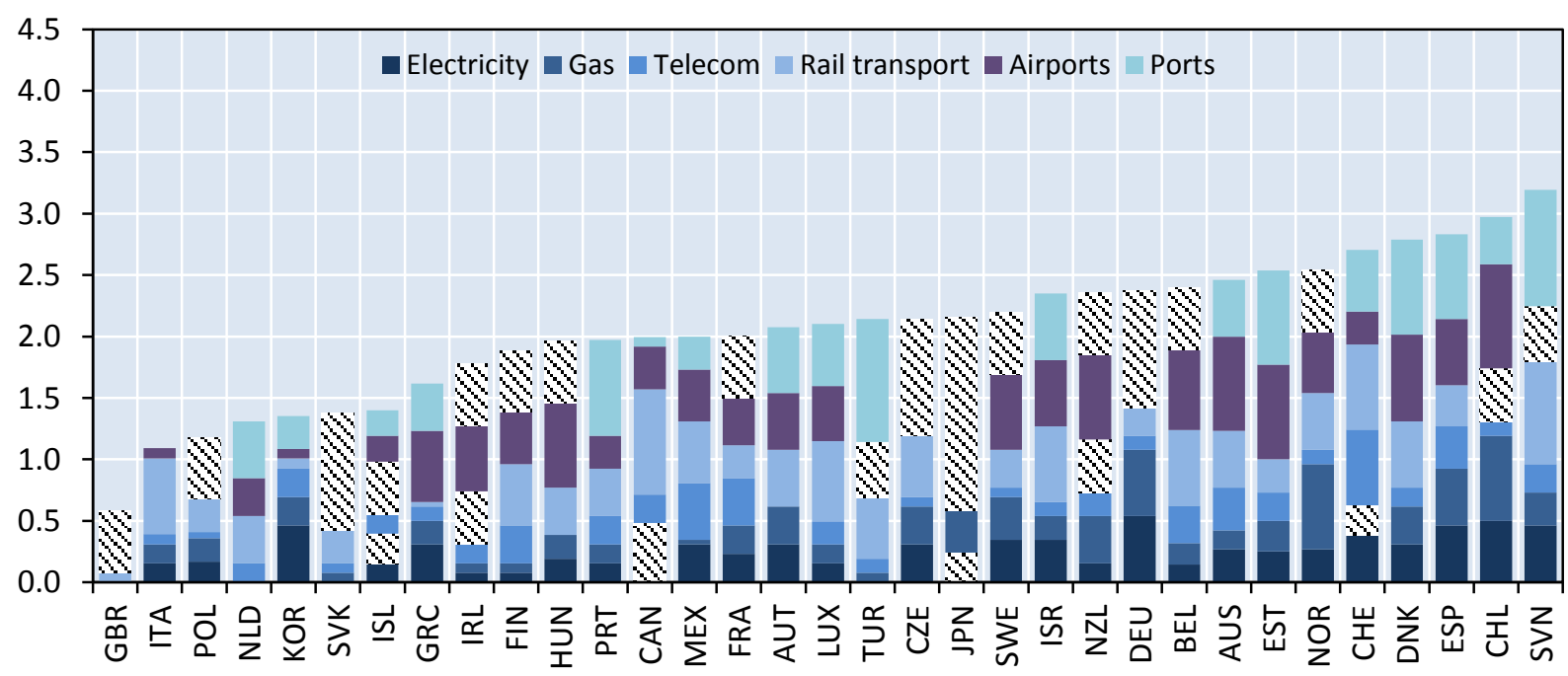

Note: The indicators vary from 0 to 6 from the most to the least effective governance structure. When data for a certain sector is missing (either because the country didn't supply the data or no regulator exists in that sector in that country) the average across all other countries is taken and the respective data are shown in black-and-whited dashes. That a country does not have an economic regulator for a certain sector applies to the following cases: gas (Iceland), rail (Chile, Iceland, New Zealand), airports (Germany, Japan), ports (Belgium, Czech Republic, Finland, Germany, Hungary, Ireland, Japan, New Zealand, Norway, Poland, Slovak Republic, Sweden, United Kingdom).

Source: OECD Product Market Regulation Database, www.oecd.org/eco/pmr.

Table 2. The regulatory management indicators tend to be positively correlated across sectors

\begin{tabular}{lcccccc}
\hline & Electricity & Gas & Telecom & Rail & Airports & Ports \\
Electricity & 1.00 & 0.71 & 0.05 & 0.08 & 0.13 & 0.09 \\
Gas & & 1.00 & 0.21 & 0.22 & 0.50 & 0.28 \\
Telecom & & & 1.00 & 0.48 & 0.28 & -0.14 \\
Rail & & & 1.00 & -0.01 & 0.06 \\
Airports & & & & & 1.00 & 0.50 \\
Ports & & & & & & 1.00 \\
\hline
\end{tabular}




\section{Regulatory management in network sectors - What does the detailed data tell us?}

\subsection{The independence of regulators}

15. The OECD Best Practice Principles on the Governance of Regulators (Governance of Regulators Principles) say that "it is important that regulatory decisions and functions are conducted with the upmost integrity to ensure that there is confidence in the regulatory regime. This is even more important for ensuring the rule of law, encouraging investment and having an enabling environment for inclusive growth built on trust". The independence of a regulator is an important factor in preventing undue influence in regulatory actions and maintaining trust in the regulatory system.

16. The questionnaire did not only ask whether a regulator is an independent body by law, but also looked at some of the procedures and requirements related to the agency's head and/or board members, including who makes their final appointment as well as the terms of their appointment in relation to renewals and any post-employment restrictions. The questionnaire also looked at whether the regulator is required to take instructions from the executive for specific activities such as long term strategies, work programmes, individual cases or decisions and appeals. Finally the source of funding of the regulator was also taken into consideration.

\section{Legal status of regulators in OECD countries}

17. The formal status (de jure) of regulators in OECD countries is similar across the electricity, gas and telecom sectors, with regulators typically being independent bodies with adjudicatory, rulemaking or enforcement powers. This stands in sharp contrast to the rail transport and ports sectors: only two-thirds of all rail regulators in OECD countries are independent with adjudicatory, rule-making or enforcement powers and none of the ports regulators has this status. In fact, all ports regulators in OECD countries are ministerial departments or agencies.

18. There are also systematic differences between EU and non-EU OECD countries (Figure 2). This is particularly the case in the electricity, gas and telecom sectors where mandatory requirements under EU law (e.g. Directive 2009/72/EC(2009)) for electricity and gas regulators, and Article 3(3a) of the Framework Directive 2002/21/EC for telecommunications sector) have led to a harmonisation of practices across countries. 
Figure 2. How is the status of the regulatory best described?

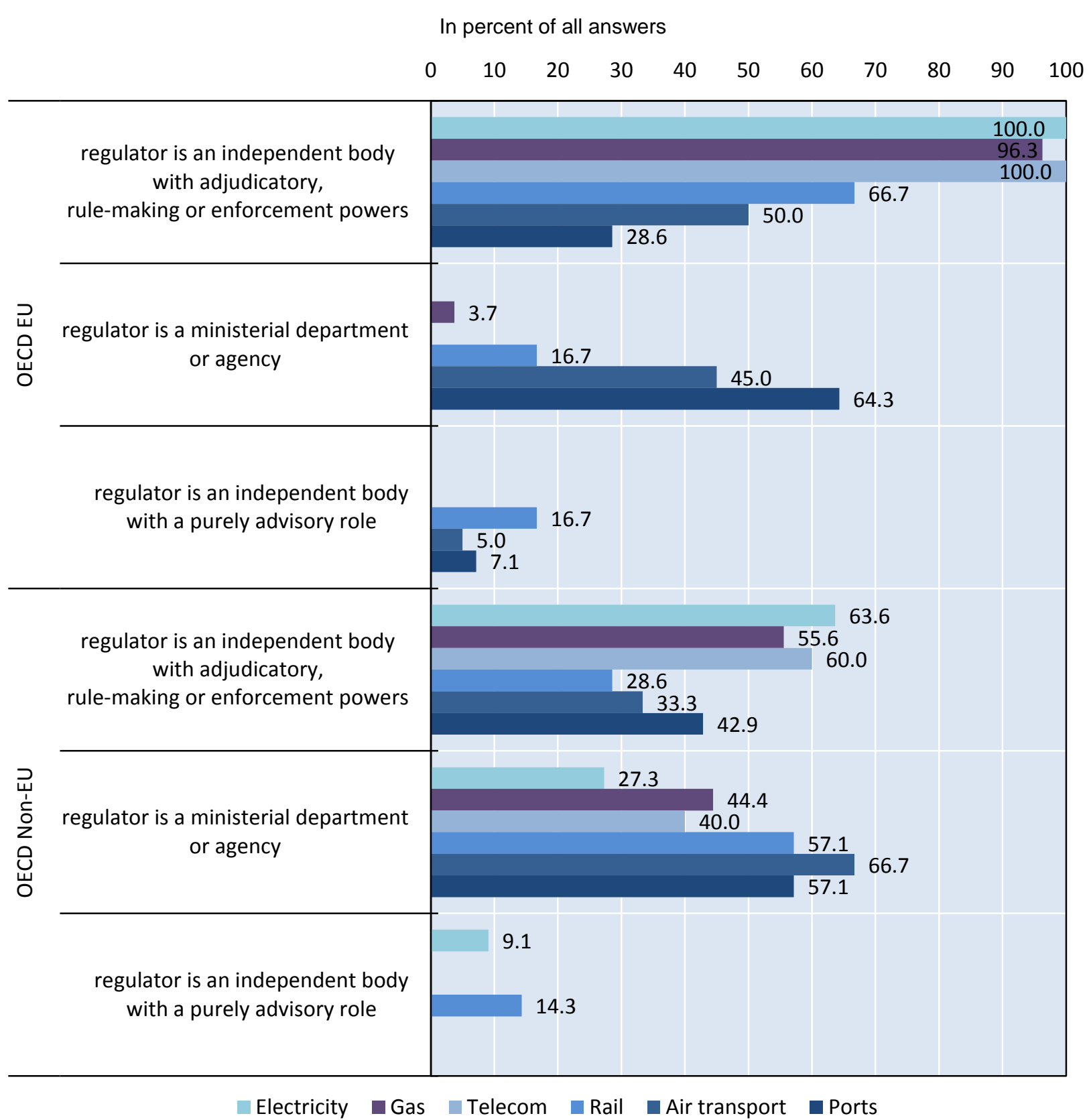

Source: OECD Regulatory Database.

19. In most cases, independent regulators that have adjudicatory, rule-making or enforcement powers have their independence stated in the law. Regulators that are ministerial departments or agencies and whose independence is explicitly stated in the law tend to be in the transport sectors. Examples of countries with an independent ministerial regulator include the Czech Republic and Italy for rail transport and Canada, France and Estonia for airports. Independence is explicitly stated in the law for half of the ports regulators which are all ministerial departments or agencies. 


\section{Financial independence}

20. Regulators generally have a dominant source of funding, with over $70 \%$ of their budget coming either from the regulated industry or the government. Exceptions include the electricity, gas and telecom regulators in Germany, the electricity regulator in Switzerland, the telecom regulator in Korea and the airport regulator in Italy.

21. Further factors for financial independence that have not been addressed in these indicators but have since been explored further in a survey of independence in 2015, include the appropriation process of the budget and whether the regulator's funding is passed to the government through an intermediary such as the legislature or directly between the funding source and the regulator. This can have an impact on independence (OECD 2015c). Another factor that determines actual financial independence is the ability of the regulator to spend the budget with a certain degree of autonomy, notwithstanding the appropriate levers of accountability (OECD 2015c).

\section{Staff appointments, requirements and post-employment restrictions}

22. The final appointment of the leadership of the regulator (head and board members) is predominantly by one government body or ministry, especially in the transport sectors. In telecom, gas and electricity sectors there are more instances of the leadership appointments being made by parliament or by two or more government bodies. Further work has shown that the nomination process itself that leads to the final appointment is an area that requires further investigation (OECD 2015c).

23. In general the head and board members cannot hold positions in government or the regulated industry while they are in appointment. Only $26.7 \%$ of regulators place restrictions on the employment history of the head or board members such as time away from being in previous employment by industry or government before taking up appointment in the agency. And only $7.4 \%$ of regulators do not permit agency heads or board members to take up any positions in the regulator sector or government after leaving the regulator. In fact, post-appointment, the majority of head or board members can take up position in government or the regulated industry, although $55.5 \%$ may only do so with some restrictions and permission from either the agency head or board and $37 \%$ had no restrictions whatsoever (Figure 3 ).

24. Incentives to ensure that relevant and competent expertise are attracted to hold leadership positions with regulatory agencies should be balanced with addressing the concern of the "revolving door" between regulator and either the executive or regulated entity. Therefore the governance structures for handling conflicts of interest and ensuring accountability of regulatory decisions is of importance (OECD 2014). 
Figure 3. Employment restrictions

In percent of all answers

Are there restrictions with regard to the employment history of the agency head/board members (e.g. minimum time away from the industry that the regulator regulates)?

May the agency head/board members hold other offices or appointments in the government or the industry that the regulator regulates?

\section{Can the agency head/board members take jobs in the} government and/or the sector that is regulated by the regulator after their term of office?

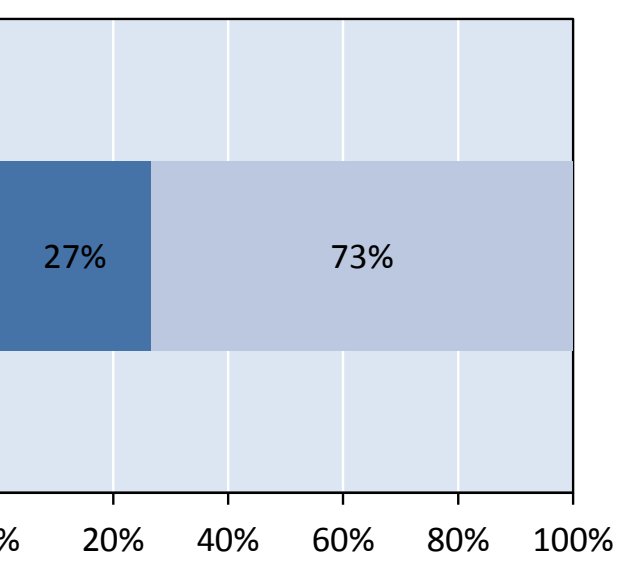

$$
\text { yes }
$$$$
\text { no }
$$
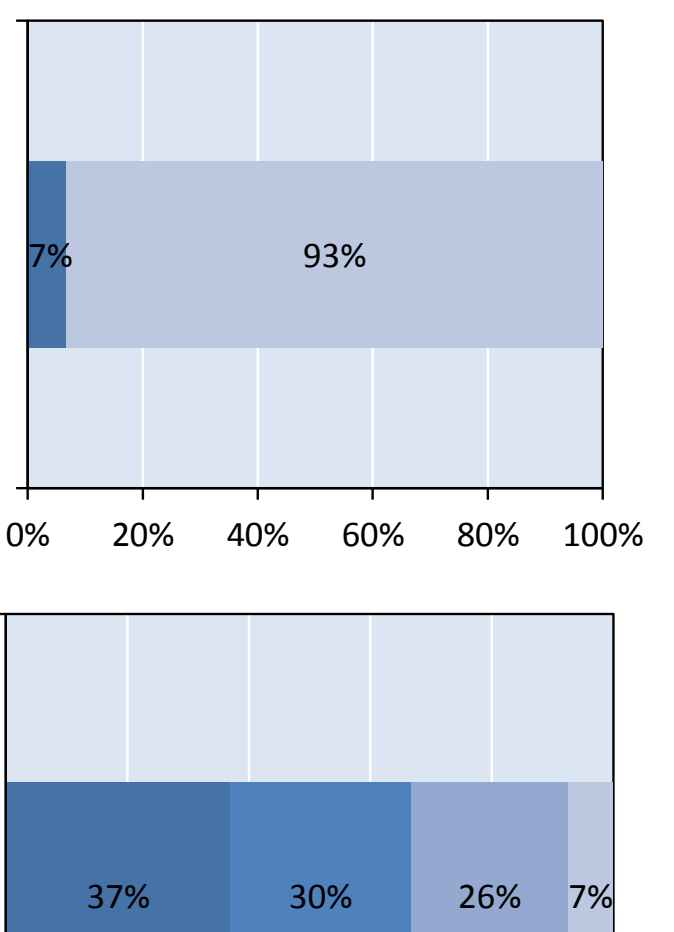

yes (without any restrictions)

yes (with the consent of the agency head)$$
\text { no }
$$
yes (after a certain
amount of time and/or with the consent of the$$
\text { (a) }
$$ 
ECO/WKP(2016)20

\section{Taking instructions from the executive}

25. Independent regulators with adjudicatory, rule-making or enforcement powers in the transport sectors commonly submit proposals for new regulation to the executive rather than parliament or another body. In the electricity, gas and telecom sectors, a large proportion of these regulators do not submit their proposals for new regulation to any other bodies, indicating that they have sufficient independence to do so unilaterally, within the scope of their legal role.

26. In general, the decisions by independent regulators in the electricity, gas, telecom and rail sectors cannot be overturned by a body other than a court, pointing to a high degree of independence. Ministerial regulators in these sectors are more likely to have decisions overturned by a government body as well as the courts, indicating a potential avenue for influence by government over the regulator. This situation is reversed for the air and ports sectors where the majority of ministerial regulators can only have decisions overturned by a court. Yet independent air and ports regulators are just as likely to have decisions overturned by a governmental or ministerial body with qualifications.

27. According to the Governance of Regulators Principles, regulators should have sufficient autonomy to conduct their functions without interference from the executive, congress or parliament. However, the long term strategy and policy goals of the regulator should be in line with the broad strategic national priorities as set by elected representatives in the executive, congress or parliament. The implementation of this principle varies considerably across sectors as demonstrated in Figure 4. While in the telecom sector, two thirds of regulators receive instructions from the government on their long-term plans, less than half of all regulators in gas and electricity sectors do so. In the transport sectors, instructions are received on the long term strategy from government or parliament in the majority of instances. This indicates a difference in formal arrangements to long-term planning in different sectors. A good practice example of independence is the Bundesnetzagentur, the federal network agency for electricity, gas, telecom, post and railway in Germany (Box 2).

28. Regulators demonstrate a greater degree of independence in their work programmes, individual cases or decisions and appeals where the majority do not receive instructions from the government. Yet, port and airport regulators are more likely to receive instructions on their operations than regulators in the other sectors.

\section{Box 2. Good practice example of independence}

The German Bundesnetzagentur displays the highest score on independence across the electricity, gas and telecom sectors. It is an independent body with adjudicatory, rule-making or enforcement powers by law. ${ }^{a}$ Moreover, it can only receive instructions from the government in exceptional circumstances. In the instance that the Federal Ministry for Economic Affairs and Energy issues instructions on the regulator's long term strategy or work programme, these instructions would have to be published online (www.bundesanzeiger.de). ${ }^{b}$ The regulator's decisions can only be appealed in court in the final instance. This points to a high ability of the regulator to act without political interference.

The agency head is appointed by the government upon recommendation from the advisory council comprised of 16 members of parliament (Bundestag) and 16 members of the Bundesrat (second chamber of parliament). The agency head has a fixed term office of 5 years, which is renewable, and may not hold other offices or appointments in the government or industry that the regulator regulates.

a. The independence of the Bundesnetzagentur is stated explicitly in the law (§1, Gesetz über die Bundesnetzagentur für Elektrizität, Gas, Telekommunikation, Post und Eisenbahnen).

b. According to $\$ 117$ Telekommunikationssgesetz. 
Figure 4. In which of the following cases can the regulator receive instructions or official guidance from the government or the parliament?

In percent of all answers

Panel A. Long-term strategy

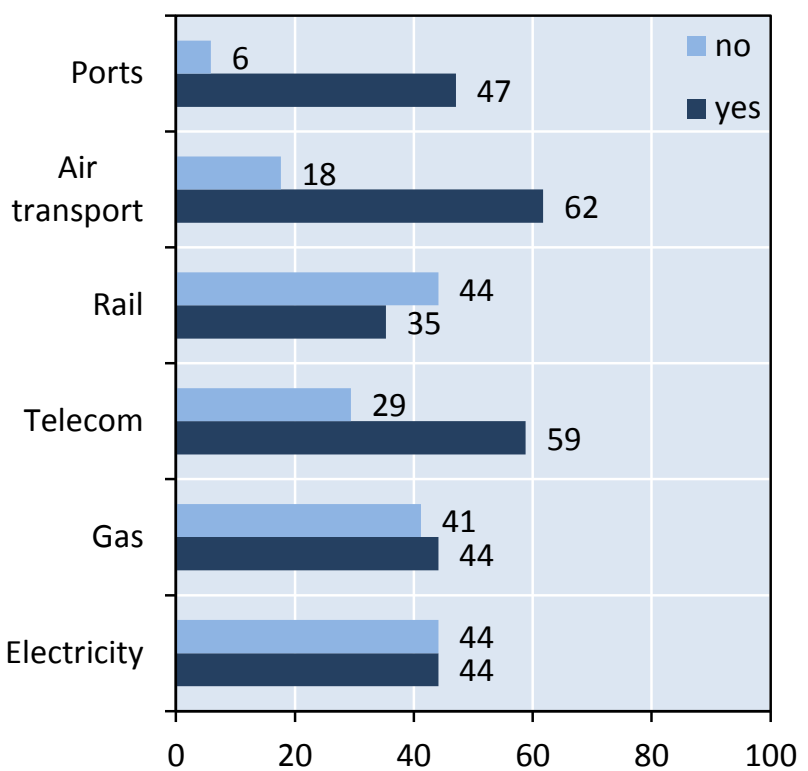

Panel C. Individual cases or decisions

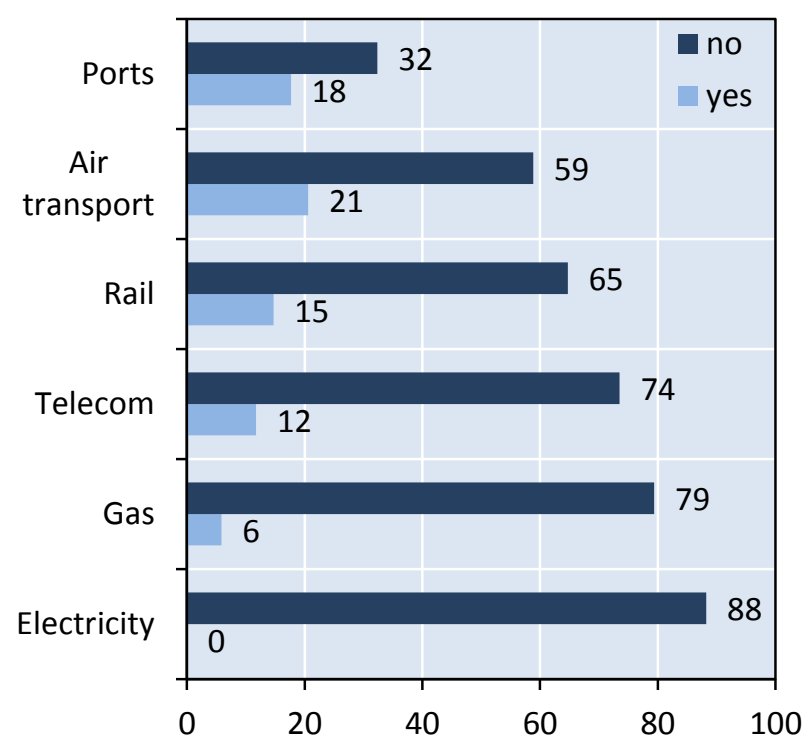

Panel B. Work programme

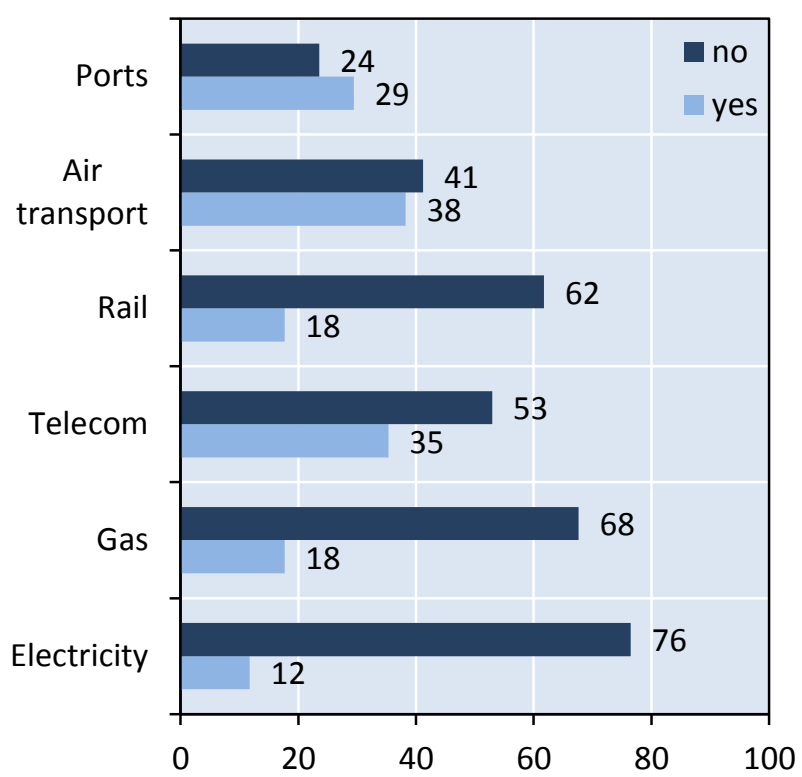

Panel D. Appeals

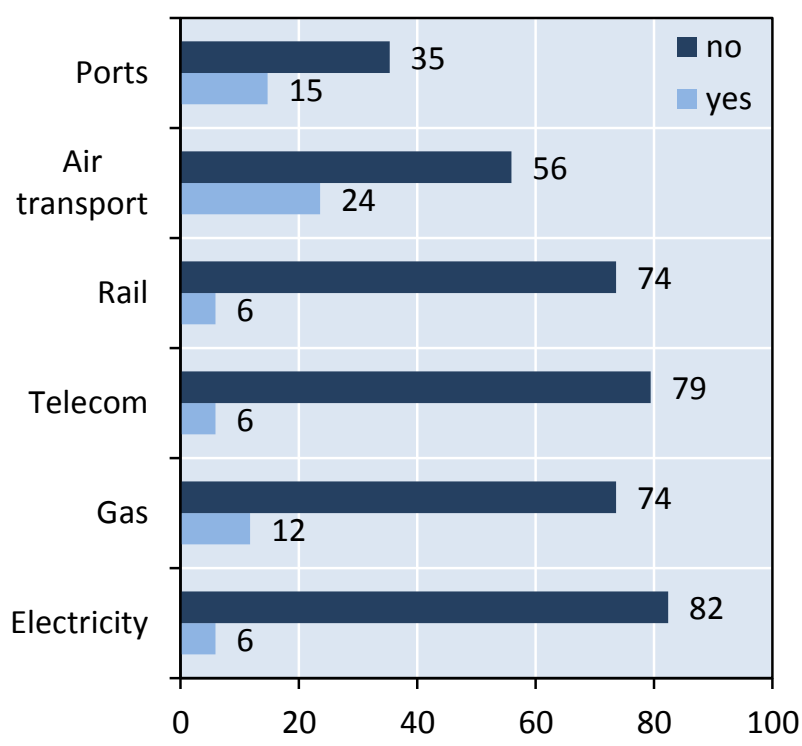

Source: OECD Regulatory Database.

\subsection{The accountability of regulators}

29. Accountability is often described as the other side of the same coin as independence. According to the Governance of Regulators Principles, mechanisms are required to ensure that public authority and 
resources are properly utilised to achieve the expected regulatory outcomes. Box 3 gives some good practice examples of accountability.

\section{Box 3. Good practice examples of accountability}

In France the electricity, gas and telecom regulators demonstrate a high level of institutional accountability by being directly accountable by law to parliament and having the regulator's objectives defined in law and published. ${ }^{a}$

The electricity regulator in New Zealand has a high level of accountability in relation to performance information. Under section 16(1)(g) of the Electricity Industry Act 2010, the New Zealand independent crown entities, the Electricity Authority and the Commerce Commission, collect a range of performance information, which can be accessed through a portal and a comprehensive data warehouse. ${ }^{b}$ The data portal supports the Authority's function "to undertake marketfacilitation measures (such as providing education, guidelines, information and model arrangements)". The legally mandated annual reports of the two agencies provide a well-structured presentation of the collected performance information in a condensed format. The achievements of the regulator during a reporting period are measured against previously specified targets and progress in achieving strategic priorities are also presented. ${ }^{c}$

a. For electricity and gas: Code de l'énergie, livre ler, titre III http://www.legifrance.gouv.fr/affichCode.do?idArticle= LEGIARTI000023985701\&idSectionTA=LEGISCTA000023985699\&cidTexte=LEGITEXT000023983208\&dateTexte=20120406; for telecommunications: Code des Postes et des Télécommunications, Art. L36-5 and http://www.legifrance.gouv.fr/ affichCode.do?cidTexte=LEGITEXT000006070987. The independence of the Bundesnetzagentur is stated explicitly in the law (§1, Gesetz über die Bundesnetzagentur für Elektrizität, Gas, Telekommunikation, Post und Eisenbahnen).

b. $\quad$ http://www.reports.ea.govt.nz/ and http://www.comcom.govt.nz/electricity-information-disclosure/

c. http://www.ea.govt.nz/about-us/documents-publications/annual-report/; http://www.comcom.govt.nz/assets/The-Commission/ Accountability/Commerce-Commission-Annual-Report-2011-12.pdf

30. In the questionnaire accountability was measured through the legal reporting requirements for performance measures and the transparency of the reporting. It also considered who the reporting is legally for. In addition, the questionnaire asked for information about the transparency in the accounting of the regulator's operations and activities and about the appeals body for regulatory decisions.

31. The database reveals that, by law, regulators are mainly accountable to the executive and not congress or parliament (Figure 5). This is especially the case for the transport sectors. A greater proportion of regulators in the telecom, gas and electricity sectors are accountable to parliament or congress by statute. The Governance of Regulators Principles recognises that regulators should be accountable to mainly three constituents; $i$ ) the executive, ii) congress or parliament and iii) citizens. Therefore accountability structures across all sectors could be improved to have more balanced accountability requirements that go beyond governments. 
Figure 5. To whom is the regulator directly accountable by law or statute?

In percent of all answers

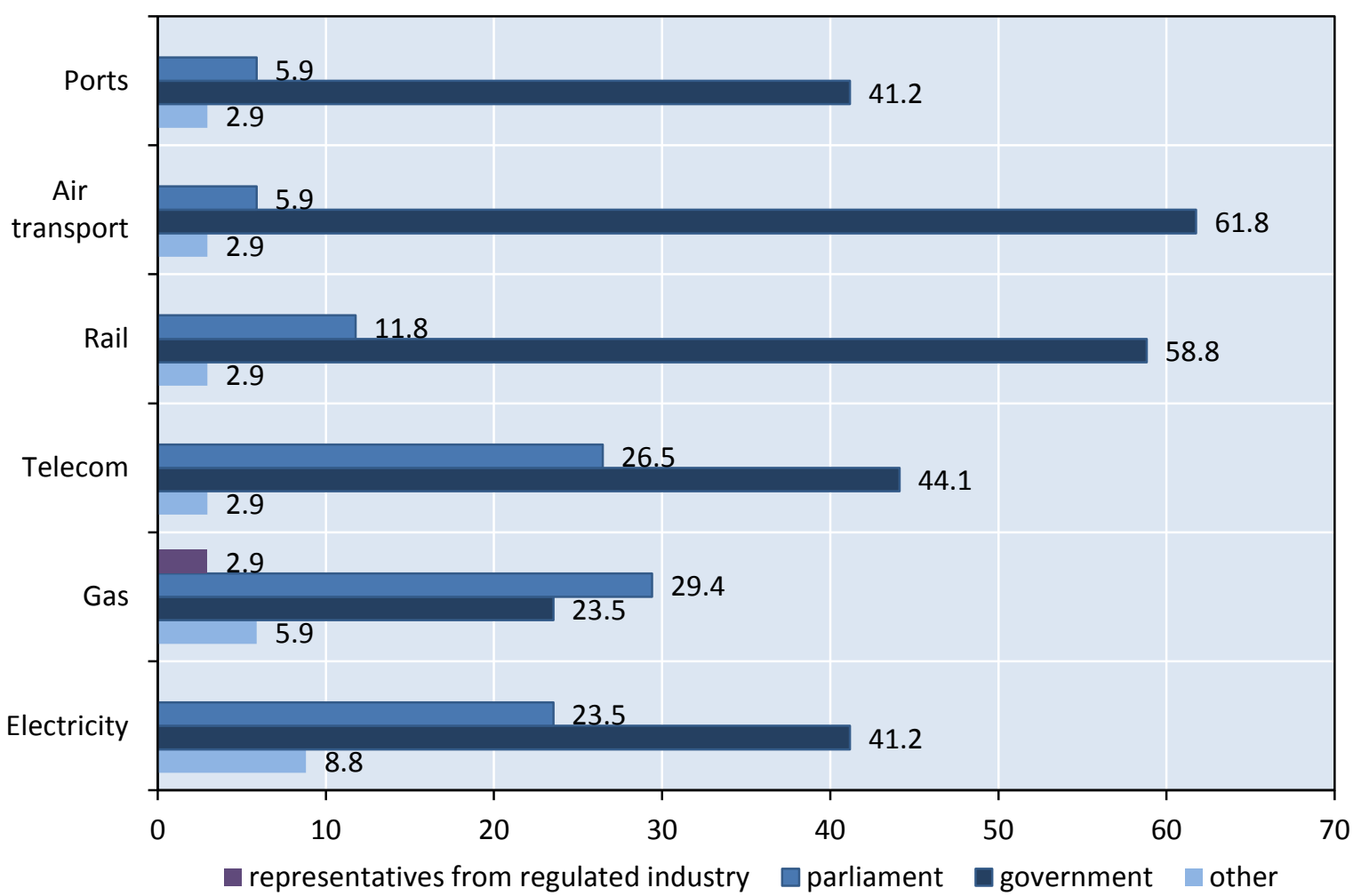

Source: OECD Regulatory Database

32. Regulators across all sectors collect a wide array of information about their performance (Figure 6). This includes information on industry and market performance, operational and service delivery (such as the number of inspections) and the organisational and corporate governance of the regulator itself. They also collect information on the regulatory process and the compliance of firms with legal obligations. The potential quality of the data collected could be examined further especially in relation to economic and financial performance and be made more accessible to the public (Figure 7). This is particularly the case in the rail transport sector where $41 \%$ of the regulators do not provide performance information over the internet. The respective figures are lowest in the telecom sector (15\%), and ports sector (21\%). Electricity $(26 \%)$, gas $(26 \%)$ and air transport $(29 \%)$ sectors also have a significant number of regulators not publishing performance information on the internet implying there is room for improvement in this area. 
Figure 6. Does the regulator collect the following performance information?

In percent of all answers

$\begin{array}{lllllllllll}0 \% & 10 \% & 20 \% & 30 \% & 40 \% & 50 \% & 60 \% & 70 \% & 80 \% & 90 \% & 100 \%\end{array}$

Industry and market performance

(e.g. number of network faults)

Operational/service delivery

(e.g. number of inspections)

Organizational/corporate governance performance

(e.g. number of staff trainings)

Quality of regulatory process

(e.g. compliance with regulatory standards)

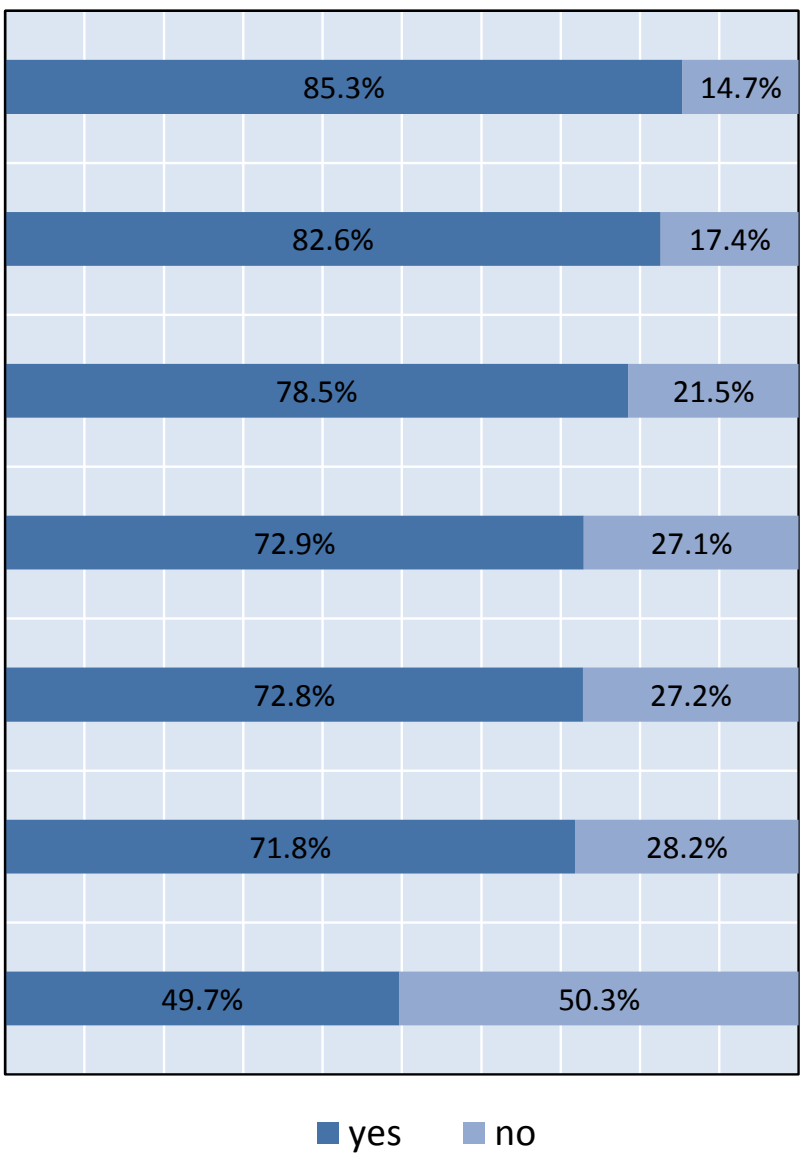

Source: OECD Regulatory Database. 
Figure 7. If such performance information is collected, is it available via the internet?

In percent of all answers

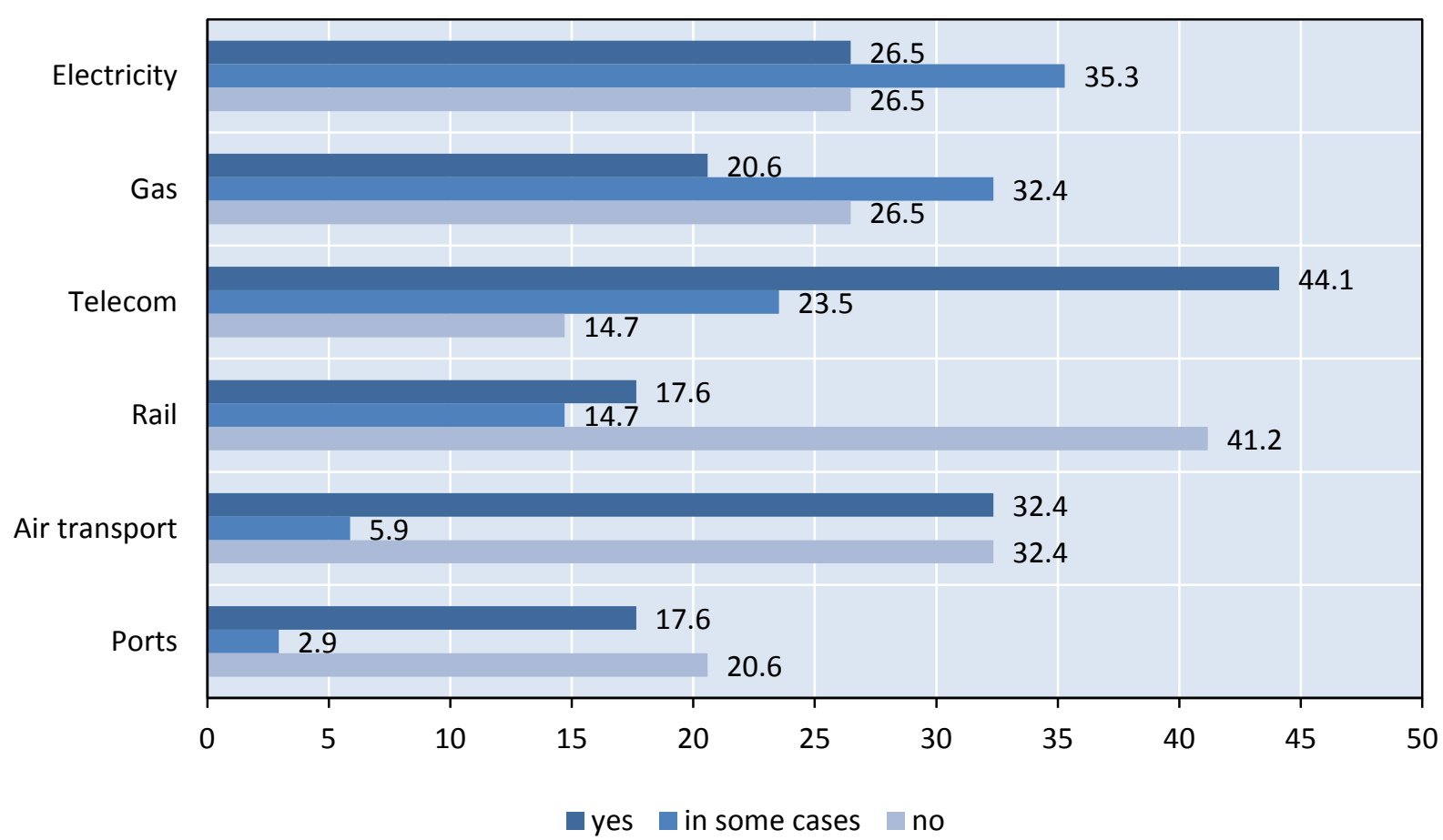

Source: OECD Regulatory Database.

33. A potential explanation for why the performance information is not readily made available to the public could be the quality of the data. Discussions by the OECD Network of Economic Regulators $(\mathrm{NER})^{10}$, which developed the Performance Assessment Framework for Economic Regulators (PAFER) ${ }^{11}$ to evaluate how regulators measure their own performance, support this gesture. The discussions at the NER have demonstrated that even though regulators do collect a wide variety of information, few are confident of its robustness and credible use to demonstrate performance of the regulator. As a result, the OECD's PAFER methodology is addressing this need for regulators and is being applied to economic regulators (OECD 2015a).

34. There is a high degree of openness regarding instructions by the government, parliament or congress on the regulators' long term strategy - in many cases such instructions have to be published. But this level of accountability is not prevalent when instruction or guidance is provided on the shorter-term work programme or operational activities. This is especially the case for the airport, port and telecom sectors. In line with the Governance of Regulators Principles, there should be stronger accountability for instructions to regulators on operational functions, in particular through greater public disclosure.

10. The NER is a forum that brings together CEOs, Commissioner and Senior Officials from economic regulators from a number of sectors, including electricity, gas, telecomm, transport and water) to help define "world class regulators". It is an official body of the OECD and is a sub-level body of the OECD's Regulatory Policy Committee, established in 2013 (see http://www.oecd.org/gov/regulatorypolicy/ner.htm).

11. The PAFER is part of the work conducted by the NER on how economic regulators measure themselves and demonstrate their added-value. The PAFER is being applied to assist economic regulators improve their governance arrangements with a focus on performance outcomes (see OECD 2015a). 


\subsection{Regulators' scope of action}

35. The institutional set up and accountability structures of regulators assists to define the types of activities that the regulator is mandated to carry out. For this reason the overall governance arrangements of the regulator are instrumental in what regulators actually do. Box 4 gives good practice examples of regulators with respect to their scope of action.

\section{Box 4. Good practice examples of regulators' scope of action}

The rail regulator in the United Kingdom, the telecomm regulator in Austria and the electricity regulator in the Netherlands are all independent bodies with adjudicatory, rule-making or enforcement powers that have the power to collect information from the regulated entities by compulsory process. They perform all of their activities independently, which include:

- Issuing and revoke licenses;

- Setting prices and/or managing price controls;

- Conducting research as an input for price setting;

- Reviewing and/or approving contract terms between regulated entities or market actors;

- Issuing industry standards;

- Issuing consumer standards;

- Issuing guidelines and/or codes of conduct;

- Enforcing compliance with industry standards and regulatory commitments;

- Mediating to resolve disputes between market actors;

- Having power to take final decisions in disputes between market actors.

36. The collected data reveal that there is the greatest difference in scope of action between ministerial regulators and independent regulators in the telecommunications and transport sectors (see Figure 8). Ministerial regulators in the telecommunications, rail, air and ports sectors tend to nearly always conduct more activities than independent regulators. Ministerial regulators in telecommunications sector had the greatest scope of action among all regulators across all sectors. This would indicate that independent regulators in the telecommunications and transport sectors are responsible for less regulatory decisions and actions than their ministerial counterparts in the same sector. In other words, there is a cost to independence in relation to the powers availed to independent regulators versus ministerial regulators in the telecommunications and transport sectors.

37. Ministerial regulators in the electricity sector conducted certain activities more than independent regulators including issuing or revoking licences, setting prices and or managing price controls, issuing consumer standards, issuing sanctions and penalties and taking final decisions in disputes between market actors. Independent regulators in the electricity sector were more likely to conduct research as an input to price setting, review and or approve contract terms between regulated entities, issue industry standards, guidelines or codes of conduct, enforce compliance with industry standards and regulatory commitments and mediate in disputes between market actors. The case of the gas sector is similar to that of the electricity sector but with Ministerial regulators also conducting research as an input to price setting and consumer standards more than independent regulators. And independent regulators in the gas sector were also more likely to mediate and take final decisions among market actors. 
Figure 8. Activities of regulators

In percent of all answers

Panel A. Issuing industry standards

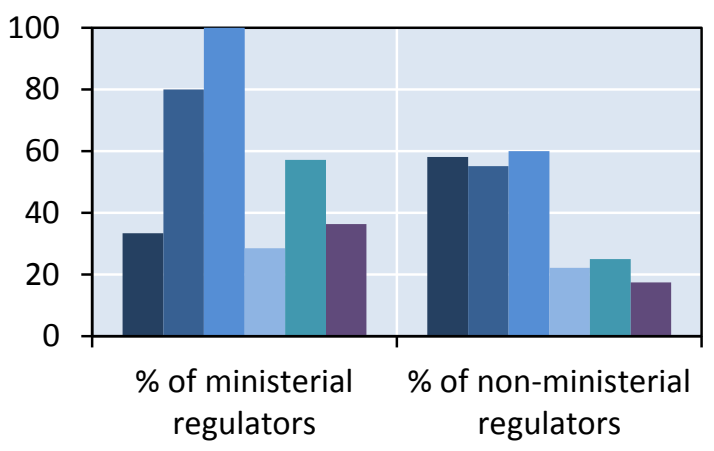

Panel C. Issuing consumer standards

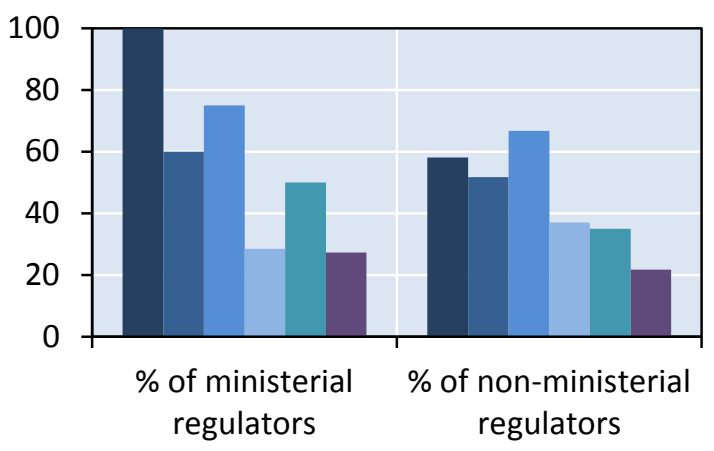

Panel E. Issuing guidelines and/or codes of conduct

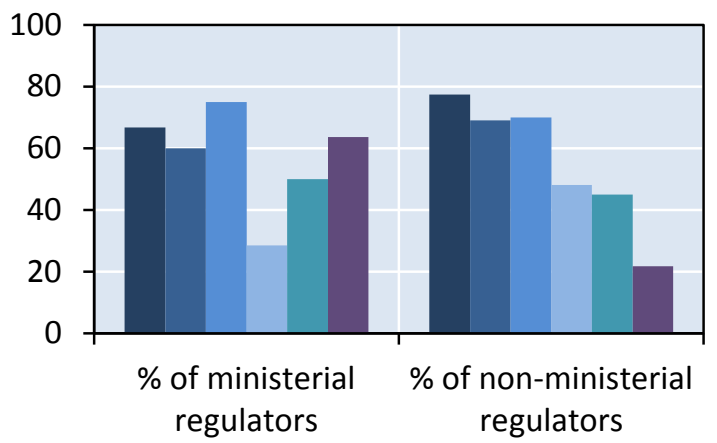

Panel G. Taking final decisions in disputes

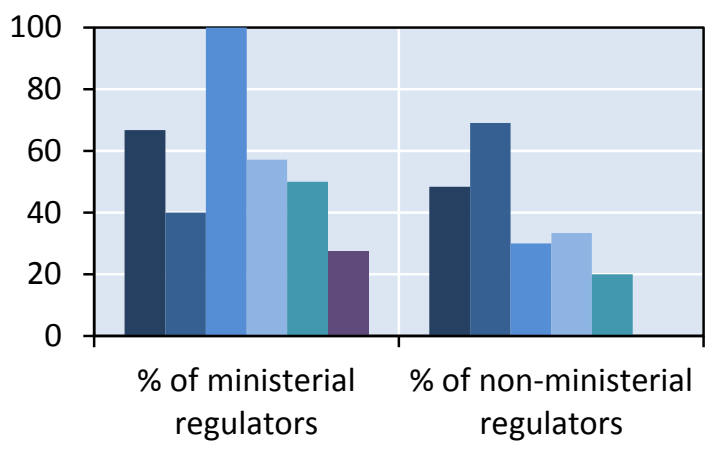

Source: OECD Regulatory Database
Panel B. Issuing sanctions and penalties

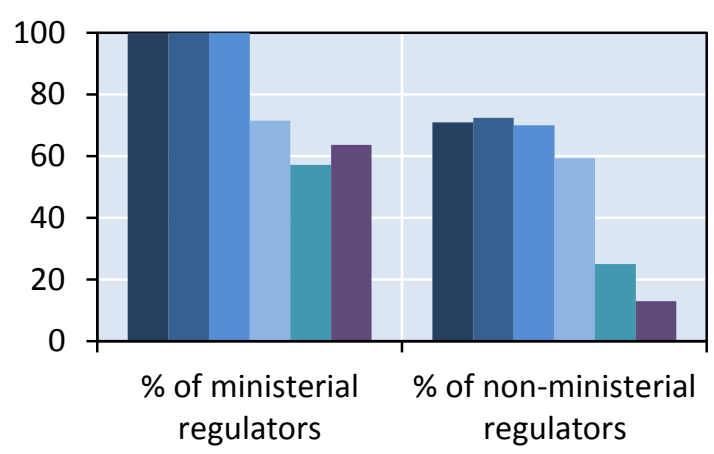

Panel D. Enforcing compliance with industry standards and regulatory commitments

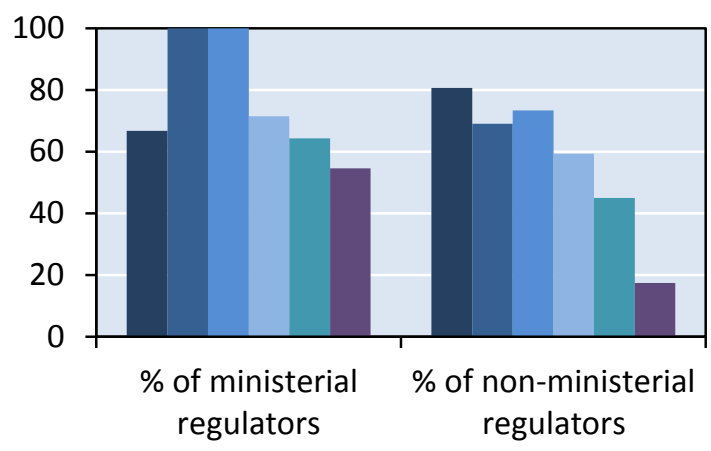

Panel F. Mediating to resolve disputes

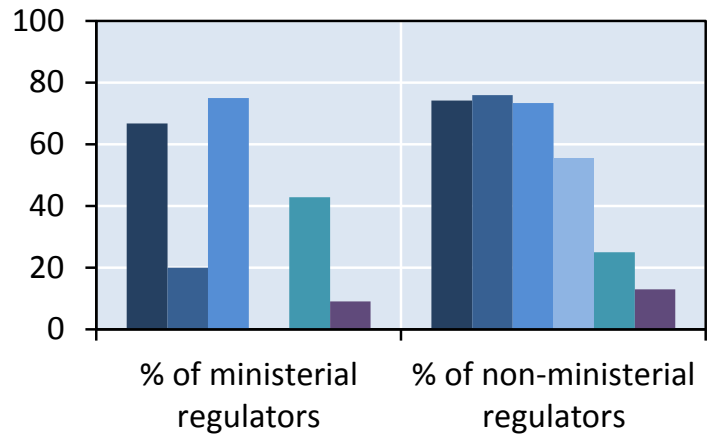


38. Regulators from all sectors are mandated to conduct a variety of functions (Figure 9). Most regulators are engaged in dispute resolution between market actors, either independently or in cooperation with another body. Specifically, $84 \%$ of all regulators mediate in disputes and $85 \%$ take final decisions in disputes. Issuing industry standards is also a common mandate for regulators, with $82 \%$ of all surveyed regulators conducting this function. These three functions are also those that regulators perform the most independently. The description of economic regulators as "referees in the market" is thus valid for OECD countries.

\section{Figure 9. Regulators' scope of action}

In percent of all answers

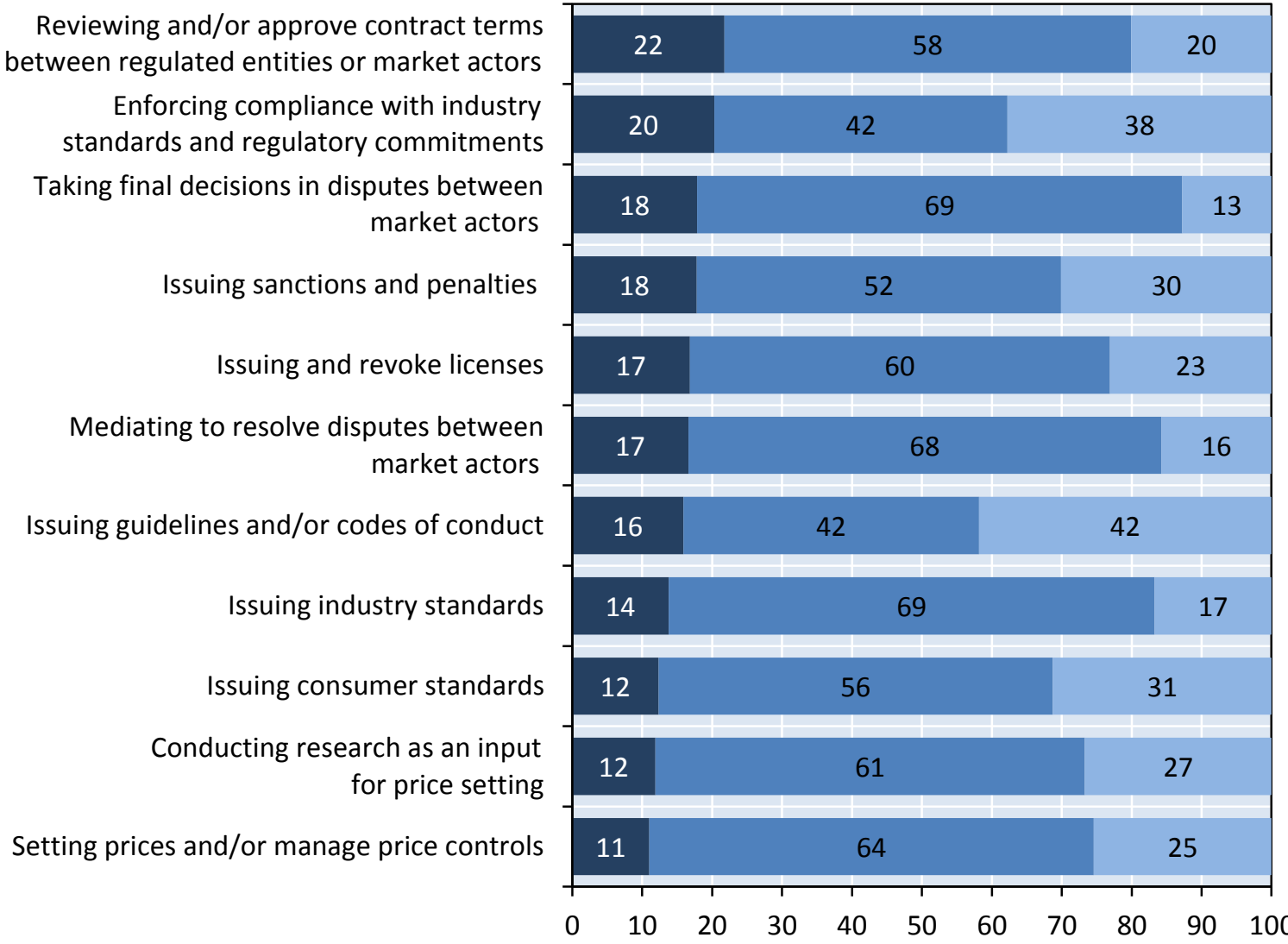

done by regulator together with other agencies/bodies (e.g. the government) independently done by regulator

not done by regulator 
39. It is also worth noting that of all the activities performed by regulators in network sectors (either independently or together with other agencies), enforcing compliance with industry standards as well as issuing sanctions and penalties are among the least common. Only 58\% and 67\%, respectively, of all regulators perform these activities. The activity that is the least common for regulators is issuing guidelines or codes of conduct (50\% of regulators do that). This potentially indicates that the use of alternatives to traditional regulation could be utilised further by regulators to obtain compliance by setting the "rules of the market" and influencing the behaviours of regulated entities and consumers.

\subsection{Specific country cases of regulatory management}

40. The survey results provide findings based on the de jure nature of network sector regulators, while acknowledging that the de facto situation may be more complex. The survey was also conducted in 2013 and there may have been changes in the setup of regulators since then. For instance the regulatory framework in Mexico has changed considerably since the survey was conducted.

41. Some specific case studies of network sector regulators have been carried using the PMR survey results and further research to provide a more in depth analysis of their current situation. They relate to network sector regulators in Australia, Latvia, Mexico and the United Kingdom.

\section{Australia: De jure versus de facto}

42. Australia performs below the OECD average across all network sectors. This reflects the context specific expression of independence, accountability and scope of action within Australia which is demonstrated by the established practices and processes in place rather than the formal and codified requirements.

43. The Australian Competition and Consumer Commission (ACCC) as the primary regulator in networks other than energy has an extensive role in regulating telecommunications, ports and water, but less so in other regulated sectors such as airports and rail where competition has been assessed as being effective and therefore not requiring a greater level of regulatory intervention. The Australian Energy Regulator (AER) is the primary energy regulator and it has an extensive regulatory role.

44. The ACCC is responsible for the economic regulation of the communications sector, including telecommunications and the National Broadband Network, broadcasting and content sectors. It has an extensive regulatory framework and has a wide scope of regulatory activities in relation to the industry including ensuring compliance for pricing and access terms of declared services, i.e. services where competition is assessed to be ineffective. The ACCC is also responsible for assessing and taking action against anti-competitive conduct in the communications sector and for consumer protection. It follows transparent and accountable practices in reaching decisions including significant stakeholder engagement, publication of submission, reporting of decisions, and judicial review of processes. There are no restrictions on the head or board members having previous history with regulated entities or government. Appointments to the ACCC are for a set term and Commissioners can only be removed under specific circumstances. The ACCC accounts for the use of resources in its Annual Report and Financial Statements, which are audited by the National Audit Office and publish regularly updated information in an easily accessible format. It is also subject to performance reporting and regularly appears before Parliament through its various Committees.

45. For the Australian Energy Regulator (AER) there are no restrictions for the head or board members in relation to previous history with regulated entities or government. Appointments follow an open and transparent process and must be agreed to by a majority of jurisdictions (national and 
sub-national governments) with responsibility for energy policy. Appointments are for a set term and can only be terminated under specific circumstances.

46. In an evaluation by the Australia Productivity Commission (APC) in 2013 concerns were expressed by government and stakeholders about the governance of the AER including its accountability, transparency, perceived lack of funding, and independence from the ACCC (Australian Productivity Commission, 2013). The APC recommended that greater funding be made available for the AER, and that the institutional independence of the AER be strengthened through separation from the ACCC, or that complete integration be executed.

47. These concerns have since been addressed. Government, through the Council of Australian Governments (CoAG) Energy Council, which represents the national and sub-national governments with responsibility for energy policy, provides the AER with a Statement of Expectations (SoE) which explicitly acknowledges that the AER is an independent statutory body. It sets out publically, and at a very high level, the Council's expectations that the AER will perform its legislative functions and implement a work program that supports the objectives set out in the national energy legislation and adopt accountable and transparent processes, including by:

- publishing a Statement of Intent for each financial year, outlining how the AER will meet the Statement of Expectations;

- publishing performance indicators in the Statement of Intent;

- reporting against performance in the AER's Annual report and in supplementary half yearly reports to CoAG;

- providing an explanation of how the AER's funds have been spent;

- effectively engage with market participants, consumers and government;

- working productively with other market institutions in accordance with legislation and memoranda of understanding; and

- supporting the CoAG Energy Council's work by providing it with advice on energy issues, reporting on the AER's priorities and work program and through clear communication on other matters as required.

48. In response, the AER publishes its Statement of Intent (SoI) for the coming year that sets out objectives, supported by details on its strategic priorities and work programme. The SoI also includes performance indicators and deliverables as required by the SoE.

49. The AER also has accountable and transparent processes across its work program. It engages in substantial and ongoing stakeholder consultation on processes, approaches and decisions on regulatory reviews, compliance and enforcement and it ensures that decisions are evidence based, clearly explained and communicated. Moreover, all decisions are subject to judicial and merits review by independent judicial bodies. 


\section{Latvia: Electricity, Gas and Telecommunications Regulator}

50. The Latvian multi-sector regulator, the Public Utilities Commission (PUC), for energy, electronic communications, post, railway transport, municipal waste management and water management performs around the OECD average according to the PMR survey.

51. It is an independent body in its decision making by law and is not subject to the decisions of the national government, local governments or other state institutions (Public Utilities Commission of Latvia, 2010a and 2010b). The PUC's decisions may be declared unlawful and repealed only by court. According to the Law on Regulators of Public Utilities the PUC's decisions can be challenged in two court instances.

52. The board is comprised of five Commissioners selected by government and appointed by the Parliament for a 5 year period. During this period the Commissioners can be removed from office only by own wish, due to illness or if convicted. The general Law on Prevention of Conflict of Interest in Activities of Public Officials applies to commissioners; additionally, the Law on Regulators of Public Utilities precludes commissioners from being members of Parliament or a local government council or holding elected offices in the management of political organisations or parties. A commissioner may not, for three years after termination of office, own or work for a utility service provider with respect to which the commissioner has made a decision.

53. In terms of its accountability structure the PUC provides an annual report to Parliament and has frequent participation in permanent commission. It engages with sectorial ministries in discussing sectorial policy and participates in the elaboration and amendments of sectorial laws and by-laws. It has ad-hoc data exchange with the Competition Authority and has bi-directional forwarding of complaints and cooperates in informative campaigns with the Consumer Rights Protection Centre. It also provides any necessary reports to the European Commission, fulfils its legal duties with official European regulatory groups and is engaged with independent European regulatory groups in consultations and preparation of European legislation.

54. The PUC performs a variety of functions including protecting customer interests; promoting the competition and the development of public service providers; issuing licenses and supervising the compliance with their requirements; supervising the compliance of services to various requirements related to quality, environmental protection, technical regulations and standards; defining tariff calculation methodologies and approving tariffs as specified in Laws and Regulations of Cabinet of Ministers; providing public information about its activities and operations of public service providers; performing preliminary out-of-court dispute settlement; and performing maintenance control of energy supply merchants' facilities and other energy supply objects in compliance with regulatory enactments of the energy sector; and supervising the safety of hydro-technical structures of hydroelectric power stations.

\section{Mexico: Post -2013 Energy Reforms}

55. The objective of the energy reforms in Mexico is to provide for a modern legal framework in order to strengthen the hydrocarbon industry by allowing the entrance of more diverse participants into the whole chain of supply, being public or non-public, domestic or international, which will increase the government revenue for the benefit of Mexicans, as well as to foster the opening of the electrical industry to allow the flow of large investments into the sector and hence dynamism and competitiveness to the economy for the benefit of the population. The energy reform does not consider the privatisation of public enterprises dedicated to hydrocarbons and electricity.

56. The Constitutional reform approved by Mexico's Congress in December 2013 grants more independence to the Comisión Reguladora de Energía or Energy Regulatory Commission (CRE) by adding 
to the technical and managerial autonomy it already had, with legal personality as well as financial independence since part of its income comes from contributions and rights in exchange for CRE services in the issuance, management and surveillance of permits, registers, as well as terms and conditions of the contracts related to the activities regulated by this commission. This higher independence is supported by stronger adjudicatory, rule-making and enforcement powers which favour autonomous regulatory decisions. The CRE was transformed into a governmental non ministerial entity, at the same hierarchical institutional level as the Ministry of Energy (Secretaría de Energía - SENER), in contrast to being a ministerial agency administratively dependant on SENER prior to the reform.

57. The energy laws, derived from the Constitutional reform, and approved by Congress in August of 2014, increased the scope of action of CRE in the electric and hydrocarbons industry. The new Electric Industry Act has significantly increased the number of powers that CRE has, including the power to determine general terms and conditions for governing retail delivery service on transmission and distribution voltages; regulate tariffs for transmission, distribution and retailers operation; issue market rules; oversee compliance within the wholesale market and the National Centre for Energy Control's (Centro Nacional de Control de la Energía - CENACE) procedures to operate the market; authorise contracts models to be used by CENACE and market participants; issue all regulation related to clean energy; authorise CENACE to conduct energy auctions; and issue regulation on electric reliability and power quality as well as a regulatory framework for the smart grid. ${ }^{12}$

58. The Law of Hydrocarbons grants more powers to the CRE, which include determining general terms and conditions for storage and transport by pipelines which include the obligation of granting third party access; regulating tariffs for storage and transport and distribution by pipelines; issuing permits for storage and transport by pipeline of petrochemicals; authorising and regulating transport operators like CENAGAS; and issuing guidelines to avoid market power including mandatory unbundling, issuance of codes of conduct, as well as caps on market share and ownership;

59. These new powers reflect the role of CRE in promoting competitive markets. By having the powers to issue consumer standards, industry guidelines and codes of conduct it has a more sophisticated role in the energy sector with a citizen-centric focus. This is further demonstrated by its new arrangements for assessing performance where more information is now collected and made available on the internet.

60. In relation to the governance arrangements for CRE the main difference is related to the length of term and the appointment mechanism or the leadership of the CRE. Previously the Head of the CRE and other Board members were designated by the executive for a staggered fixed term of five years with the possibility of being reappointed once. Since the reforms, the board has been expanded from five to seven Commissioners and it is the Senate that makes the appointment based on the proposal of the Executive. The length of the term is now seven years, which is longer than the term of the administration.

61. The CRE has greater financial independence with its budget coming from a combination of government and the regulated industry, instead of only from government. Moreover, there are increased accountability measures for new regulatory proposals. Proposals for new regulations will now be submitted directly by CRE to the Federal Commission for Regulatory Improvement (Comision Federal de Mejora Regulatoria - COFEMER) which is responsible for promoting regulatory quality including ensuring transparency in the regulation-making and implementation process and that the benefits outweigh the costs. Also, CRE will have now two advisory bodies, each for the hydrocarbons and electricity sectors, constituted by all the stakeholders (consumers, industry, academy and other authorities). Finally there are

12. The former CRE Act granted 20 powers for both hydrocarbon and electric sectors and the Renewable Energy Act granted 7 powers. The new Electric Industry Act provides 52 powers. 
also specific obligations to publish relevant data on the webpage of CRE and more powers to collect information from the industry.

\section{United Kingdom: Electricity and Gas Regulator}

62. The Office for Gas and Electricity Markets (Ofgem) performs around the OECD average for independence, but demonstrates a high level of accountability and scope of action. This seems to be the general trend for the United Kingdom network regulators. Ofgem's own principles for transparency and accountability are:

- Transparency - providing clear, consistent, comparable and accessible information;

- Accountability - so that decision-makers and budget holders can be held to account;

- Simplicity - so that it is easy to understand what is going on; and

- Coherence - so that our activities are clear and logical

63. The functions and activities that Ofgem conducts include issuing and revoking licenses; setting prices and/or manage price controls; conducting research (e.g. about costs) as an input for price setting; review and/or approving contract terms between regulated entities or market actors; issuing industry and consumer standards as well as guidelines/codes of conduct; enforcing compliance with industry standards and regulatory commitments; issuing sanctions and penalties; mediating to resolve disputes between market actors and taking the final decisions in such disputes. The enforcement powers that Ofgem has range from enforcing licence conditions, competition law and consumer protection law to market investigation references.

64. While Ofgem is an independent regulator it has a high degree of accountability. Each year, Ofgem produces a Forward Work Programme. The Programme provides information on the work to be undertaken to support the main themes and priorities. It also provides financial data. Based on the Forward Work Programme, the regulator makes its planned deliverables and performance indicators for the year ahead available. They account for the use of resources in Annual Reports and Accounts, which are audited by the National Audit Office and publish regularly updated information in an easily accessible format. The accountability requirements are stated by the Department of Energy and Climate Change (2011) and a memorandum by Ofgem to the British Parliament (Ofgem, 2003).

\section{Conclusions}

65. This paper presents a new set of unique indicators that capture in a comprehensive way a number of key aspects of the governance of regulators responsible for energy, telecommunications and transport. The indicators focus on the regulatory governance arrangements as stipulated in law or statute to provide a picture of what regulators look like and what they do. The indicators demonstrate the importance of understanding the institutional arrangements and differences among countries in an attempt to then understand the outcomes in the relevant network sectors. An initial analysis of the indicators confirms the complexity of governance arrangements in relation to the independence, accountability and scope of action of network regulators in OECD countries. Balancing the levels of the three is the key question within any given political context with differing market structures. 
ECO/WKP(2016)20

Figure 10. Balancing independence, accountability and scope of action

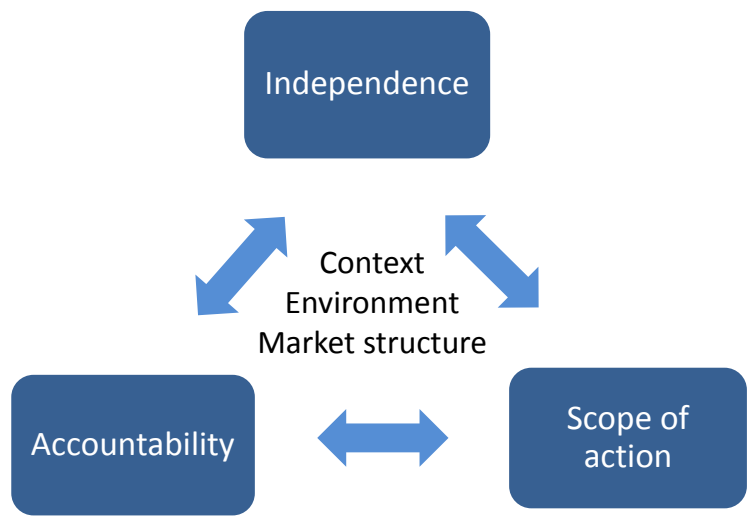

66. Some interesting findings on the institutional design of regulators have emerged, such as ministerial regulators generally are able to conduct more activities than independent regulators across all sectors, among the three least activities conducted by regulators there are the functions of enforcing compliance and issuing sanctions, and regulators tend to be formally accountable to the executive (rather than parliament).

67. This paper also provides inputs for further work on the governance and performance of economic regulators. On the governance of economic regulators, the indicators mostly provide a de jure or formal description of economic regulators. Some of the country cases presented in the paper, however, suggest that there could be some gaps between formal and informal arrangements. For example, regardless of the source of funding of the regulator, undue influence on the regulator could happen through the budget negotiation or the timeline of the appropriation procedure. Nonetheless the de jure status of regulators will have an impact on the "culture of independence" of regulators. This is an area for further exploration and analysis that the OECD is developing through a survey conducted among NER members on one of the aspects explored by the indicators, namely the de facto situation of the independence of economic regulators (OECD 2015c).

68. On the performance of economic regulators, the indicators can offer a key contribution to analyse the relationship between governance arrangements and the overall performance of a sector or industry (for example, as measured by investment or productivity). More specifically on the work of economic regulators, the analysis presented in this paper suggests that performance evaluation of regulators across all sectors is an area for improvement. There is evidence that regulators collect a variety of data on performance but this is not always published. This finding has been confirmed during the meetings of the NER where an evaluation framework has been developed and is being applied by economic regulators (OECD 2015b). This work is expected to continue to complement the data presented in this paper with indepth assessments of the practice and decision-making processes developed by regulators to better understand the driver of performance and identify good practices for regulating a sector. 


\section{REFERENCES}

Australian Productivity Commission (2013), “Electricity Network Regulatory Frameworks”, Productivity Commission Inquiry Report, Vol. 2, pp. 770-797.

Berg, S. (2000), "Sustainable Regulatory Systems: Laws, Resources, and Values," Utilities Policy, Vol. 9 , No. $4,159-70$

Bourlès, R. et al. (2010), "Do Product Market Regulations in Upstream Sectors Curb Productivity Growth: Panel Data Evidence for OECD Countries", OECD Economics Department Working Papers, No. 791.

Bouis, R. and R. Duval (2011), "Raising Potential Growth after the Crisis: A Quantitative Assessment of the Potential Gains from Various Structural Reforms in the OECD Area and Beyond", OECD Economics Department Working Papers, No. 835.

Brown, A., J. Stern, and B. Tenenbaum (2006), Handbook for Evaluating Infrastructure Regulatory Systems, (The World Bank: Washington D.C.) xx-397

Burns, P., Jenkins, C., M. Mikkers and C. Reichmann (2007), "The Role of the Policy Framework for the Effectiveness of Benchmarking in Regulatory Proceedings," in Coelli and Lawrence, op. cit.

Conway, P., D. de Rosa, G. Nicoletti, and F. Steiner (2006), "Regulation, Competition and Productivity Convergence", OECD Economics Department Working Papers, No. 509.

Conway, P., V. Janod and G. Nicoletti (2005), "Product Market Regulation in OECD Countries: 1998 to 2003”, OECD Economics Department Working Papers, No. 419.

Department of Energy and Climate Change (2011), Ofgem Review, https://www.gov.uk/government/ publications/ofgem-review-final-report

Eko, L. (2010), "Many Spiders, One Worldwide Web: Towards a Typology of Internet Regulation”, Communication Law and Policy, Vol. 6, pp. 445-484.

Gilardi, F. and M. Maggetti (2010), “The Independence of Regulatory Authorities”, in: D. Levi-Faur (ed.), Handbook on the politics of regulation, Edward Elgar Publishing, Cheltenham, United Kingdom.

Gutierrez, Luis H. (2003), "The Effect of Endogenous Regulation on Telecommunications Expansion and Efficiency in Latin America", Journal of Regulatory Economics, 23(3):257-86.

Jarvis, Darryl S.L and Sovacool, Benjamin K (2011), Conceptualizing and Evaluating Best Practices in Electricity and Water Regulatory Governance, Energy, 36, 4340-4352.

Kim, S. and A. Horn, (1999), "Regulation Policies Concerning Natural Monopolies in Developing And Transition Economies," Discussion Paper No. 8 of the United Nations Department of Economic and Social Affairs.

Kovacic, W. E. (2011), "Competition Agencies, Independence and the Political Process" in: J. Drexl et al. (eds), Competition Policy and the Economic Approach Foundations and Limitations. Edward Elgar Publishing, pp. 291-311. 
Nicoletti, G. and S. Scarpetta (2005), "Product Market Reforms and Employment in OECD Countries", OECD Economics Department Working Papers, No. 472.

Nicoletti, G., S. Scarpetta and O. Boylaud (1999), "Summary Indicators of Product Market Regulation with an Extension to Employment Protection Legislation", OECD Economics Department Working Papers, No. 226.

OECD (2008), "Resolution of the Council on the Seoul declaration for the future of the Internet economy", http://olisweb.oecd.org/vgn-ext-templating/C(2008)99-

ENG.pdf?docId=JT03248284\&date $=1214322652000 \&$ documentId=446947\&organisationId $=1 \&$ file Name=JT03248284.pdf.

OECD (2010), "The protection of children online - Risks faced by children online and policies to protect them", http://search.oecd.org/officialdocuments/displaydocumentpdf/?cote=dsti/iccp/reg (2010)5/final\&doclanguage $=$ en .

OECD (2011a), "OECD Council recommendation on principles for Internet policy making", http://www.oecd.org/sti/ieconomy/49258588.pdf.

OECD (2011b), "The Internet economy: generating innovation and growth", Summary of the Chair of the OECD high level meeting, http://www.oecd.org/internet/innovation/48348748.pdf.

OECD (2012a), "Recommendations of the Council on Regulatory Policy and Governance", http://www.oecd.org/gov/regulatory-policy/49990817.pdf.

OECD (2012b), "Report on Consumer Protection in Online and Mobile Payments", OECD Digital Economy Papers, No. 204, OECD Publishing, Paris.

OECD (2013a), "Exploring Data-Driven Innovation as a New Source of Growth: Mapping the Policy Issues Raised By Big Data", OECD Publishing, Paris, http://search.oecd.org/officialdocuments/ publicdisplaydocumentpdf/?cote $=$ DSTI/ICCP(2012)9/FINAL \& docLanguage $=$ En DSTI/ICCP(2012)9/FINAL.

OECD (2013b), "Broadband Networks and Open Access", OECD Digital Economy Papers, No. 218, OECD Publishing, Paris.

OECD (2013c), "Protecting And Empowering Consumers in the Purchase of Digital Content Products", OECD Digital Economy Papers, No. 219, OECD Publishing, Paris.

OECD (2014), "OECD Best Practice Principles for Regulatory Policy: The Governance of Regulators", OECD Publishing, Paris, http://www.oecd.org/regreform/governance-of-regulators.htm.

OECD (2015a), Driving Performance at Columbia's Communication Regulator, OECD Publishing, Paris, http:/dx.doi.org/10.1787/9789264232945-en

OECD (2015b), The Governance of Water Regulators, OECD Studies on Water, OECD Publishing, Paris.

OECD (2015c), Being an Independent Regulator: The what and the how, OECD Publishing, Paris.

Ofgem (2003), Memorandum by Ofgem, http://www.publications.parliament.uk/pa/ld200304/ldselect/ ldconst/68/3052109.htm. 
Public Utilities Commission of Latvia (2010a), Role and Functions of an Independent Regulator, http://www.erranet.org/index.php?name=OE-eLibrary\&file=download\&id=6861\&keret= N\&showheader $=\mathrm{N}$.

Public Utilities Commission of Latvia (2010b), Annual Report of the Public Utilities Commission of the Republic of Latvia on the National Energy Sector, www.ceer.eu/portal/page/portal/EER.../C11_NR_ Latvia-EN.pdf

Sutherland, D. et al. (2011), "Public Policies and Investment in Network Infrastructure", OECD Journal: Economic Studies, Vol. 2011/1. http://dx.doi.org/10.1787/eco_studies-2011-5kg51mlvk6r6

Thatcher, M. (2005), "The Third Force? Independent Regulatory Agencies and Elected Politicians in Europe", Governance, Vol. 18, pp. 347-373.

Weiser, P. J. (2009), “The Future of Internet Regulation”, mimeo.

Weller D. and B. Woodcock (2013), "Internet Traffic Exchange: Market Developments and Policy Challenges", OECD Digital Economy Papers, No. 207, OECD Publishing.

Wölf, A., Wanner, I., T. Kozluk, and G. Nicoletti (2009), „Ten Years of Product Market Reforms in OECD Countries - Insights From a Revised PMR Indicator", OECD Economics Department Working Papers, No. 695. 


\section{ANNEX: THE SCORING SYSTEM OF THE REGULATORY MANAGEMENT INDICATORS}

69. This Annex provides further details on the methodology used to compute the indicators on regulatory management in network sectors. The indicator of each of the six sectors (electricity, gas, telecommunication, rail, airports, and ports) is based a bit more than 50 questions that capture the governance structure of the sector regulator. All of these questions are closed questions that can be answered by selecting an answer from a pre-defined set of menu (e.g. the question whether the regulator needs to perform a specific type of activity can be answered with 'yes' or 'no'). The qualitative information is transformed into quantitative information by assigning a numerical value to each possible response to a given question. The coded information is normalised over a zero to six scale, where a lower value reflects a more effective governance structure. Tables A1 to A3 explain in detail how the three components of the regulatory management indicators (independence, scope of action, accountability). 
Table A1. Independence

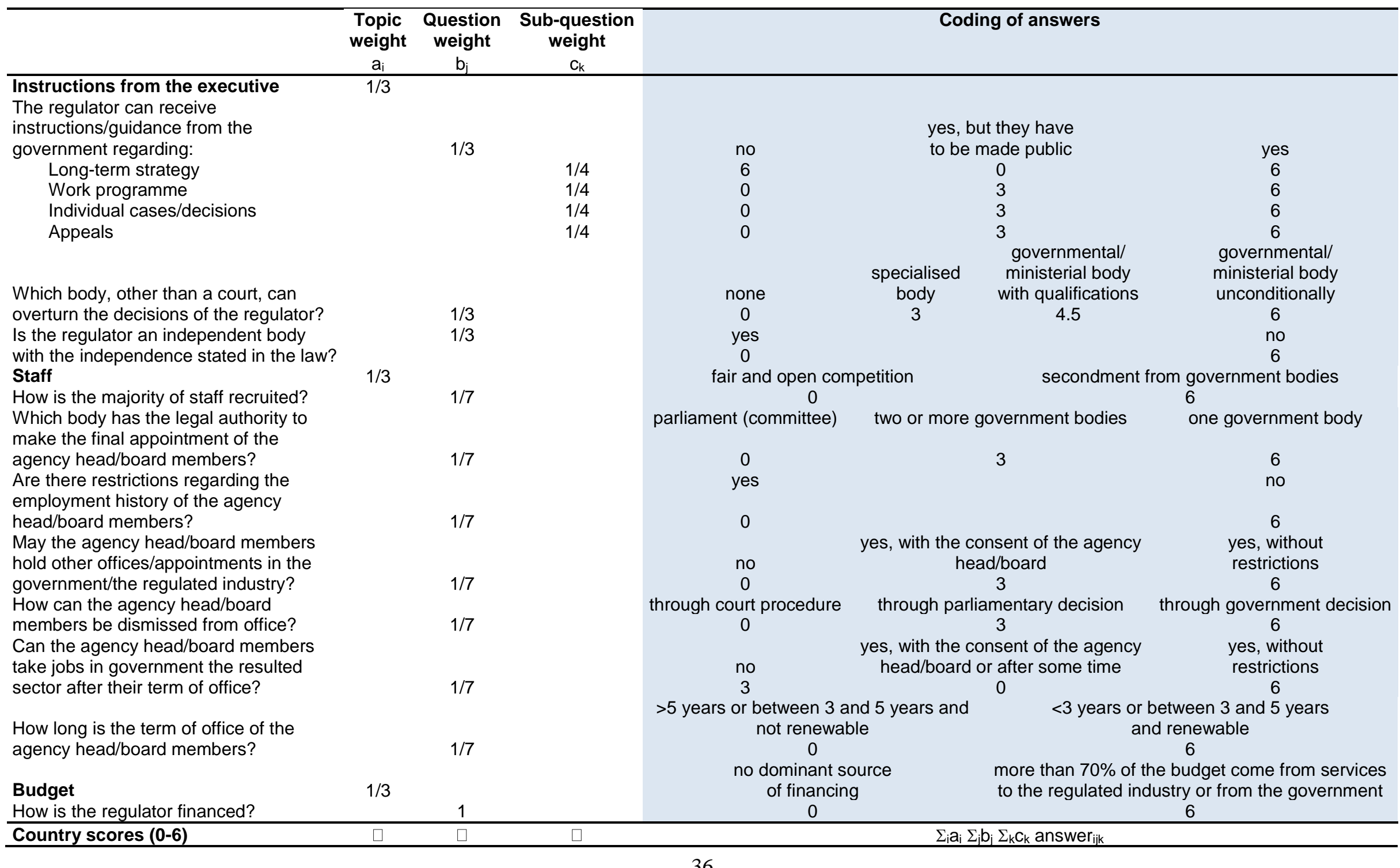


Table A2. Scope of action

ECO/WKP(2016)20

\begin{tabular}{|c|c|c|c|c|}
\hline & $\begin{array}{c}\text { Question } \\
\text { weight } \\
a_{i} \\
\end{array}$ & & Coding of answers & \\
\hline & & $\begin{array}{l}\text { independent body with } \\
\text { adjudicatory, rule-making or } \\
\text { enforcement powers }\end{array}$ & $\begin{array}{l}\text { independent body with purely } \\
\text { advisory role }\end{array}$ & ministerial department/agency \\
\hline What is the status of the regulator? & $1 / 13$ & 0 & 3 & 6 \\
\hline Can the regulator collect information from the & & yes & & no \\
\hline regulated entities by compulsory process? & $1 / 13$ & 0 & & 6 \\
\hline & & & $\begin{array}{l}\text { yes, together with other } \\
\text { agencies/bodies such as the }\end{array}$ & \\
\hline & & yes, independently & government & no \\
\hline Does the regulator issue and revoke licenses? & $1 / 13$ & 0 & 3 & 6 \\
\hline controls? & $1 / 13$ & 0 & 3 & 6 \\
\hline $\begin{array}{l}\text { Does the regulator conduct research (e.g. about } \\
\text { costs) as an input for price setting? } \\
\text { Does the regulator review and/or approve contract }\end{array}$ & $1 / 13$ & 0 & 3 & 6 \\
\hline $\begin{array}{l}\text { terms between regulated entities or market actors? } \\
\text { Does the regulator issue industry standards (e.g. }\end{array}$ & $1 / 13$ & 0 & 3 & 6 \\
\hline $\begin{array}{l}\text { standards related to efficiency or security of supply)? } \\
\text { Does the regulator issue consumer standards (e.g. } \\
\text { standards related to bills transparency, minimum } \\
\text { contractual conditions, switching of service }\end{array}$ & $1 / 13$ & 0 & 3 & 6 \\
\hline $\begin{array}{l}\text { providers)? } \\
\text { Does the requlator issue quidelines and/or codes of }\end{array}$ & $1 / 13$ & 0 & 3 & 6 \\
\hline $\begin{array}{l}\text { conduct? } \\
\text { Does the requlator enforce compliance with industry }\end{array}$ & $1 / 13$ & 0 & 3 & 6 \\
\hline standards and regulatory commitments? & $1 / 13$ & 0 & 3 & 6 \\
\hline Does the regulator mediate to resolve disputes & & & & \\
\hline $\begin{array}{l}\text { between market actors? } \\
\text { Does the regulator have the power to take final }\end{array}$ & $1 / 13$ & 0 & 3 & 6 \\
\hline decisions in disputes between market actors? & $1 / 13$ & $\begin{array}{l}0 \\
\text { done independently by agency } \\
\text { or by court or by agency together }\end{array}$ & $\begin{array}{l}\text { 3 } \\
\text { yes, together with other } \\
\text { agencies/bodies such as the }\end{array}$ & 6 \\
\hline Can the regulator issue sanctions and penalties (e.g. & & with court & government & no \\
\hline financial)? & $1 / 13$ & 0 & 3 & 6 \\
\hline Country scores $(0-6)$ & $\square$ & & $\sum_{\mathrm{i}} \mathrm{a}_{\mathrm{i}}$ answer $\mathrm{i}_{\mathrm{i}}$ & \\
\hline
\end{tabular}


Table A3. Accountability

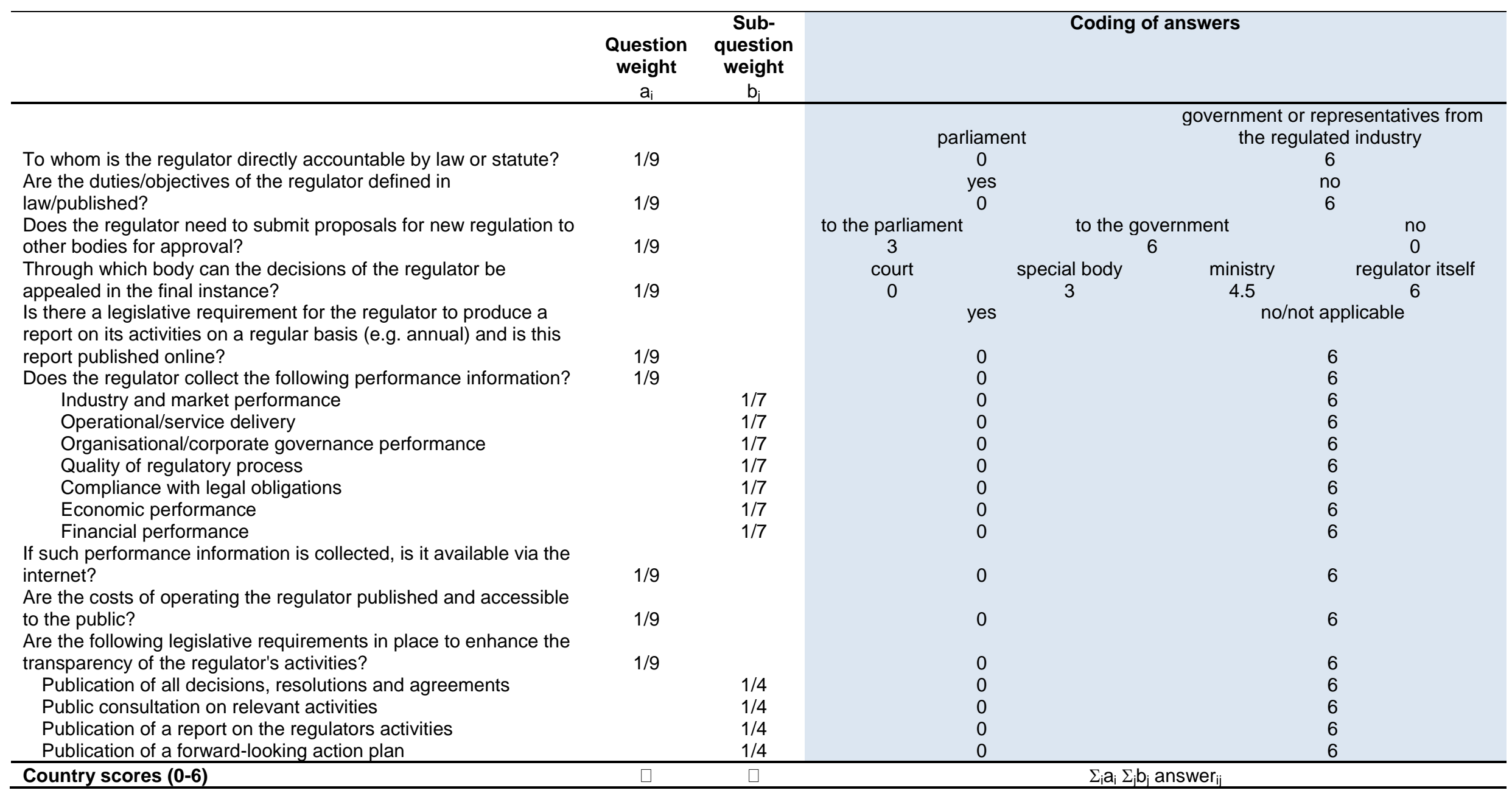

